\title{
An Examination of the Regional Supply and Demand Balance for Renewable Electricity in the United States through 2015
}

\section{Projecting from 2009 through 2015}

Lori Bird, David Hurlbut, Pearl Donohoo, Karlynn Cory, and Claire Kreycik

Technical Report NREL/TP-6A2-45041

Revised June 2010

Original publication date: March 2009 


\section{ERRATA SHEET}

NREL REPORT/PROJECT NUMBER: TP-6A2-45041

TITLE: An Examination of the Regional Supply and Demand Balance for Renewable Electricity in the United States through 2015 (Revised)

SUBTITLE: Projecting from 2009 through 2015

AUTHOR(S): Lori Bird, David Hurlbut, Pearl Donohoo, Karlynn Cory, and Claire

Kreycik

ORIGINAL PUBLICATION DATE: March 2009

DATE OF CORRECTIONS: June 2010

The following corrections were made to this report:

In the Demand-Side Analysis section, subsection titled Compliance (RPS) Markets, Table 16 (Page 22) was modified to correct a miscalculation of compliance market demand in Montana. In addition to Table 16, Figure 3 (Page 23) is amended to reflect the revisions.

In the Supply and Demand Balance section, calculation errors impacted estimates of shortages and surpluses in the West, California, and the Midwest between 2010 and 2015. In the revised version of the report, Figure 4 (Page 24) - also Figure ES-1 (Page 2) Table 17 (Page 28), and Table 18 (Page 29) are modified. The conclusions in the text of this section were unaffected.

In Appendix B, the supply/demand graphs for the Midwest (Figure B1, Page 39), California (Figure B8, Page 42), and the West (Figure B9, Page 43) are also revised. 


\section{An Examination of the Regional Supply and Demand Balance for Renewable Electricity in the United States through 2015}

\section{Projecting from 2009 through 2015}

Lori Bird, David Hurlbut, Pearl Donohoo, Karlynn Cory, and Claire Kreycik

Prepared under Task No. IGST.8370

Technical Report NREL/TP-6A2-45041

Revised June 2010

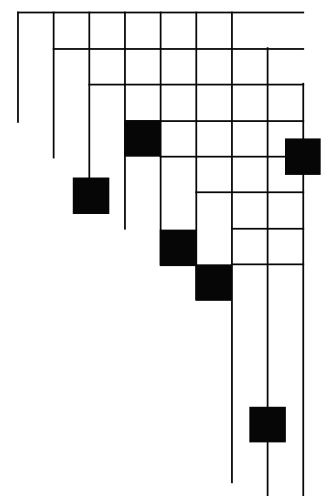

National Renewable Energy Laboratory 1617 Cole Boulevard, Golden, Colorado 80401-3393 303-275-3000 • www.nrel.gov 


\section{NOTICE}

This report was prepared as an account of work sponsored by an agency of the United States government. Neither the United States government nor any agency thereof, nor any of their employees, makes any warranty, express or implied, or assumes any legal liability or responsibility for the accuracy, completeness, or usefulness of any information, apparatus, product, or process disclosed, or represents that its use would not infringe privately owned rights. Reference herein to any specific commercial product, process, or service by trade name, trademark, manufacturer, or otherwise does not necessarily constitute or imply its endorsement, recommendation, or favoring by the United States government or any agency thereof. The views and opinions of authors expressed herein do not necessarily state or reflect those of the United States government or any agency thereof.

Available electronically at http://www.osti.gov/bridge

Available for a processing fee to U.S. Department of Energy and its contractors, in paper, from:

U.S. Department of Energy

Office of Scientific and Technical Information

P.O. Box 62

Oak Ridge, TN 37831-0062

phone: 865.576.8401

fax: 865.576 .5728

email: mailto:reports@adonis.osti.gov

Available for sale to the public, in paper, from:

U.S. Department of Commerce

National Technical Information Service

5285 Port Royal Road

Springfield, VA 22161

phone: 800.553 .6847

fax: 703.605.6900

email: orders@ntis.fedworld.gov

online ordering: http://www.ntis.gov/ordering.htm 


\section{Acknowledgments}

This work was funded by the U.S. Department of Energy's (DOE) Office of Energy Efficiency and Renewable Energy (EERE). The authors wish to thank Linda Silverman, John Atcheson, as well as EERE's Weatherization and Intergovernmental Program (WIP) and the Office of Planning, Budget, and Analysis (PBA) for their support of this work. The authors also wish to thank Galen Barbose of Lawrence Berkeley National Laboratory, Ed Holt of Ed Holt and Associates Inc., Charles Kubert of the Clean Energy Group, Kevin Porter of Exeter Associates, and David Kline of NREL for their thoughtful review of the document, as well as Michelle Kubik of NREL for her editorial support. 


\section{List of Acronyms}

\begin{tabular}{|c|c|}
\hline $\mathrm{ACP}$ & Alternative compliance payment \\
\hline ARRA & American Recovery and Reinvestment Act \\
\hline AWEA & American Wind Energy Association \\
\hline BAU & Business as usual \\
\hline CREZ & Competitive Renewable Energy Zone \\
\hline CSP & Concentrating solar power \\
\hline DOE & Department of Energy (U.S.) \\
\hline DSIRE & Database of State Incentives for Renewables and Efficiency \\
\hline EIA & Energy Information Administration \\
\hline ERCOT & Electric Reliability Council of Texas \\
\hline EPA & Environmental Protection Agency \\
\hline EERE & Energy Efficiency and Renewable Energy (Office of) \\
\hline ETNNA & Environmental Tracking Network of North America \\
\hline GEA & Geothermal Energy Association \\
\hline GW & Gigawatts \\
\hline GWh & Gigawatt hours \\
\hline IREC & Interstate Renewable Energy Council \\
\hline ISO & Independent system operator \\
\hline ITC & Investment tax credit \\
\hline LBNL & Lawrence Berkeley National Laboratory \\
\hline LMOP & Landfill Methane Outreach Program \\
\hline MRO & Midwest Reliability Organization \\
\hline MSW & Municipal solid waste \\
\hline MW & Megawatts \\
\hline MWh & Megawatt hours \\
\hline NERC & North American Electric Reliability Corporation \\
\hline NWTC & National Wind Technology Center \\
\hline PBA & Planning, Budget, and Analysis \\
\hline PPA & Power purchase agreements \\
\hline PUCT & Public Utility Commission of Texas \\
\hline PV & Photovoltaic \\
\hline REC & Renewable energy certificate \\
\hline ReEDS & Regional Energy Deployment System (model) \\
\hline RPS & Renewable portfolio standard \\
\hline RTO & Regional transmission organization \\
\hline SEIA & Solar Energy Industries Association \\
\hline SPP & Southwest Power Pool \\
\hline TVA & Tennessee Valley Authority \\
\hline TWh & Terawatt hours \\
\hline $\mathrm{UCS}$ & Union of Concerned Scientists \\
\hline WECC & Western Electricity Coordinating Council \\
\hline WGA & Western Governors' Association \\
\hline WIP & Weatherization and Intergovernmental Program \\
\hline
\end{tabular}




\section{Table of Contents}

Acknowledgments ..............................................................................................................ii

List of Acronyms ................................................................................................................ iv

List of Tables ........................................................................................................................... iv

List of Figures............................................................................................................................ vi

Executive Summary .......................................................................................................... 1

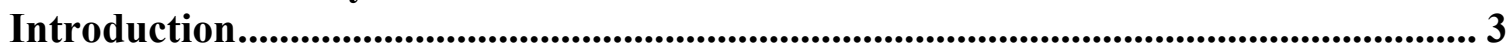

Assumptions and Methodology................................................................................................. 5

Focus on New Renewable Energy Capacity ………….......................................... 5

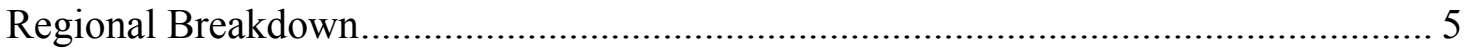

Supply-Side Analysis ......................................................................................................... 9

Estimates of Current Installed New Capacity (Through 2006) ....................................... 9

Estimates of Generation from Installed Facilities (Through 2006) .............................. 11

Supply Projection Methodology (2007-2015) ........................................................ 12

Supply Estimates, by Technology and Region ........................................................... 16

Demand-Side Analysis................................................................................................................ 19

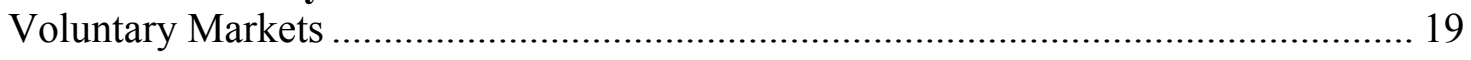

Compliance (RPS) Markets ...................................................................................... 21

Sum of Voluntary and Compliance Market Demand ................................................... 23

The Supply and Demand Balance ........................................................................... 24

Key Uncertainties............................................................................................................... 30

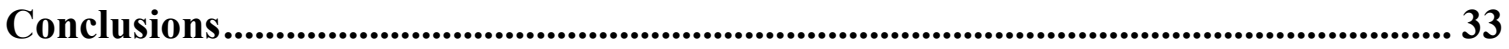

References............................................................................................................................... 35

Appendix A. Planned Geothermal and CSP Projects ...................................................... 38

Appendix B. Regional Balances .............................................................................................. 39

\section{List of Tables}

Table 1. Geographic Eligibility Requirements for States with RPS ................................. 8

Table 2. Cumulative "New" Renewable Energy Capacity by Technology through 2006

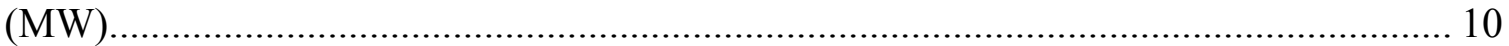

Table 3. Cumulative "New" Renewable Energy Capacity by Region through 2006 (MW)

Table 4. Wind Capacity Factors for Study Regions ……………………………………. 11

Table 5. Renewable Energy Generation by Technology, 2004-2006 (GWh)................... 12

Table 6. Renewable Energy Generation by Region, 2004-2006 (GWh) ......................... 12

Table 7. Projected Cumulative Installed New Renewable Energy Capacity by Resource,

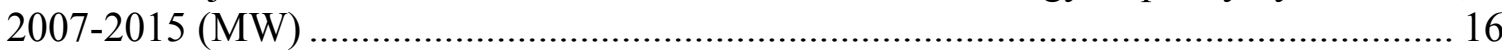

Table 8. Projected Cumulative Installed New Renewable Energy Capacity by Region:

Business as Usual Case, 2007-2015 (MW)................................................................. 17

Table 9. Projected Cumulative Installed New Renewable Energy Capacity by Region:

High Wind Case, 2007-2015 (MW) ......................................................................... 17

Table 10. Projected Renewable Energy Generation by Technology, 2007-2015 (GWh) 18 
Table 11. Projected Renewable Energy Generation: Business as Usual Case, 2007-2015 (GWh)

Table 12. Projected Renewable Energy Generation: High Wind Case, 2007-2015 (GWh)

Table 13. Voluntary Demand by Region, 2004-2007 (GWh) ........................ 20

Table 14. Projected Voluntary Demand by Region, 2008-2015 (GWh) ......................... 20

Table 15. Compliance Requirements by Region for "New" Renewable Energy, 2004-

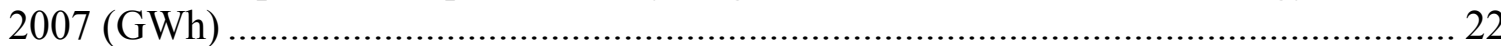

Table 16. Compliance Requirements by Region for "New" Renewable Energy, 20082015 (GWh) 22

Table 17. Business as Usual Case: Renewable Energy Generation Net of Regional RPS Demand and Regional Voluntary Renewables Demand (GWh) …….......................... 28 Table 18. High Wind Case: Renewable Energy Generation Net of Regional RPS Demand and Regional Voluntary Renewables Demand (GWh) ……......................................... 29

Table A1. Geothermal Developing Projects by Phase .................................................. 38

Table A2. CSP Developing Projects by Phase............................................................. 38

\section{List of Figures}

Figure ES-1. Snapshot of regional demand and supply under the two cases in 2015

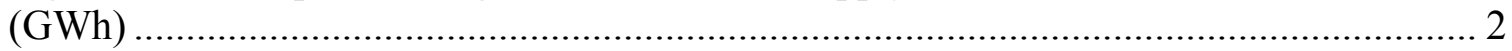

Figure 1. Supply and demand regions as defined in the analysis .................................... 7

Figure 2. Wind supply projections compared to 20\% wind scenario .............................. 14

Figure 3. Historic and projected demand for "new" renewable energy, 2004-2015 ........ 23

Figure 4. Regional demand and supply under the two cases in 2010 and 2015 (GWh) ... 24

Figure B1. Supply and demand projections in the Midwest, 2004-2015 (MWh)............ 39

Figure B2. Supply and demand projections for New England, 2004-2015 (MWh) ........ 40

Figure B3. Supply and demand projections in New York, 2004-2015 (MWh)............... 40

Figure B4. Supply and demand projections in the Mid-Atlantic, 2004-2015 (MWh)..... 40

Figure B5. Supply and demand projections in the Heartland, 2004-2015 (MWh) .......... 41

Figure B6. Supply and demand projections in the Southeast, 2004-2015 (MWh) ........... 41

Figure B7. Supply and demand projections in Florida, 2004-2015 (MWh) .................... 42

Figure B8. Supply and demand projections in California, 2004-2015 (MWh) ............... 42

Figure B9. Supply and demand projections in the West, 2004-2015 (MWh) ................. 43

Figure B10. Supply and demand projections in Texas, 2004-2015 (MWh) .................... 43 


\section{Executive Summary}

This report examines the balance between the demand and supply of new renewable electricity in the United States on a regional basis through 2015. It expands on a 2007 NREL study (Swezey et al. 2007) that assessed the supply and demand balance on a national basis. As with the earlier study, this analysis relies on estimates of renewable energy supplies compared to demand for renewable energy generation needed to meet existing state renewable portfolio standard (RPS) policies in 28 states, as well as demand by consumers who voluntarily purchase renewable energy. However, it does not address demand by utilities that may procure cost-effective renewables through an integrated resource planning process or otherwise.

The analysis examines two supply scenarios: 1) a business as usual (BAU) scenario based on current growth rates in renewable energy supply in each region and 2) a market-based scenario that differs only in an assumed higher overall level of wind energy development nationally (based on estimates from BTM Consult and referred to as "high wind case"). Because the BTM Consult (2008) projections are only available nationally, and are not broken out regionally, this analysis uses results from a recent study by DOE (DOE 2008) that presents a scenario of $20 \%$ wind energy penetration by 2030 to apportion the wind energy capacity by region.

The BAU case estimates future wind energy capacity using regression analysis that accounts for the accelerated growth in capacity additions from 2005-2008 for each region. The lower bound of the $95 \%$ confidence interval is applied to reflect a worst-case scenario based on extending historical trends. Under both scenarios, the estimates of nonwind renewables are based on current growth rates or account for planned capacity additions, which are derated to account for uncertainty. Estimates of future solar capacity assume that solar carve-outs in existing state RPS policies will be met; although this assumption is arguably optimistic, the long-term extension of the federal investment tax credit and availability to utilities may make this feasible.

While the high wind case is a high case overall with respect to wind energy capacity additions nationally, the BAU case shows higher growth in wind energy capacity for some years in a few regions where wind energy capacity has shown recent rapid growth (e.g., Texas and the Midwest).

The analysis found an overall national surplus of renewable energy generation to meet existing RPS policy targets and voluntary market demand over the study period. However, based on the assumptions in this analysis, there are some projected regional shortages, as well as regions with excess supplies. Figure ES-1 compares the two supply scenarios to renewable energy demand from RPS policies and voluntary markets in each of the regions considered in this analysis in 2015.

If trends hold, renewable energy deficits are projected for New England, New York, and the Mid-Atlantic areas, with notable surpluses in the Midwest, the Heartland, Texas, and the West. The BAU scenario, which is based on an extrapolation of recent development 
trends, found an internal shortfall for California, while under the high wind energy scenario, California had excess generation except for one year (2010). This analysis does not assume trading between the regions specified in the analysis, although in some cases such trading may be feasible to the extent it is not limited by transmission access or state RPS renewable energy certificate (REC) trading rules. For example, shortages in California, which is treated as an independent region in the analysis, could possibly be offset by surplus supply projected elsewhere in the West to the extent it can meet California's deliverability requirements.

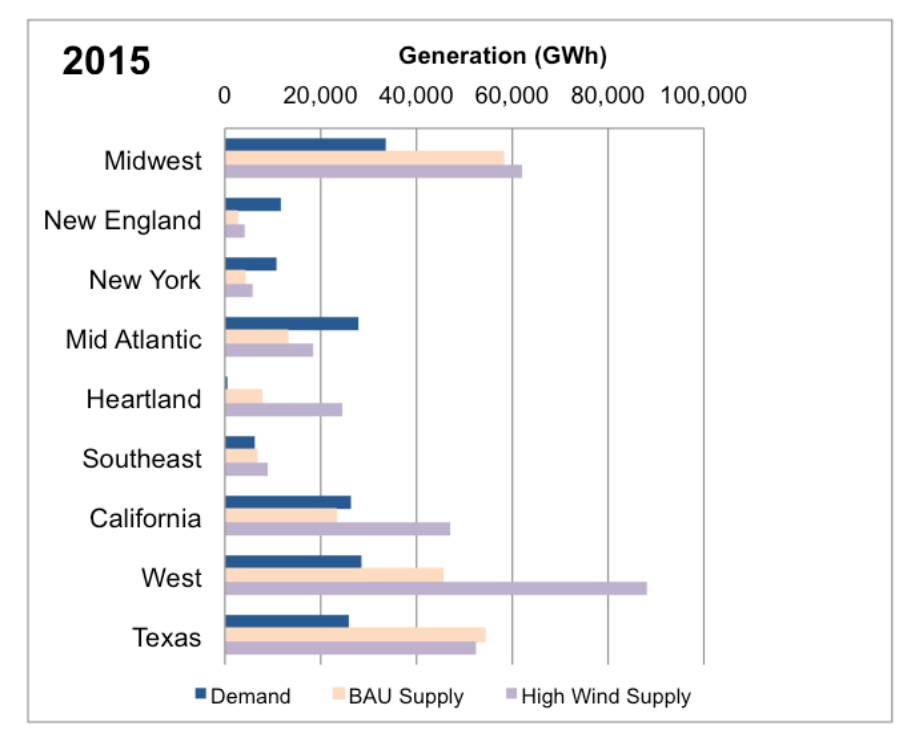

Figure ES-1. Snapshot of regional demand and supply under the two cases in 2015 (GWh)

In addition to interregional transfers where transmission is available, shortfalls could be addressed through price signals that may accelerate development of renewable energy resources that are currently uneconomic. This is particularly true in areas that have no or few market barriers.

In areas with market barriers or transmission constraints, removing barriers to development, adding new transmission, and expanding interregional REC trading could alleviate potential regional shortfalls and enable states to access least-cost renewables.

There are a number of key uncertainties in this analysis, including the impact of the global financial crisis as well as changes in incentives or policies. This analysis reflects existing policies, except those established very recently under the American Recovery and Reinvestment Act, signed into law by President Barack Obama in February 2009. The effects of the financial crisis are still unclear at this time, but it is possible that a lack of access to project financing in the short term could delay some project development and shift it to later years. While the pace of development in coming years will depend on the ability of the federal government and the financial industry to address the financial crisis and increase the availability of debt for project financing, the estimates presented here have not accounted for potential impacts of the crisis, because they are highly uncertain. 


\section{Introduction}

State and federal policies, the growth of voluntary green power purchase markets, and the improving economics of renewable energy development have accelerated the demand for renewable energy. A number of states have adopted renewable portfolio standards (RPS), requiring that renewable energy sources be used to supply a certain fraction of retail electricity sales; and many of these states recently expanded their targets significantly. Today, 28 states plus the District of Columbia have RPS requirements, with renewable energy targets ranging from $2 \%$ to $40 \%$ of total electricity supply, to be achieved over the next five to 15 years. At the end of 2007, these combined RPS policies - which cover $46 \%$ of the nation's electricity load - called for utilities to procure about 16 million megawatt hours (MWh) of new renewable energy generation. Going forward, they are expected to drive the development of more than 30,000 MW of new renewable energy capacity by 2015 if fully met (Wiser and Barbose 2008).

Voluntary consumer purchases of renewable energy have grown rapidly, primarily because more companies are purchasing renewable energy certificates (RECs) equivalent to their electricity needs. In addition, participation in utility green pricing programs is growing and more utilities are offering programs. The National Renewable Energy Laboratory (NREL) estimates that voluntary purchases of renewable energy from electricity providers and retail REC marketers by residential and business consumers totaled approximately 18 million MWh at the end of 2007, an increase of approximately $50 \%$ from the previous year (Bird et al. 2008).

A previous study by NREL found that aggregate U.S. demand for renewable energy resulting from current policies is growing so quickly that capacity growth would need to accelerate to keep pace (Swezey et al. 2007). Another recent study by Lawrence Berkeley National Laboratory (LBNL) found that some states have not achieved full compliance for their RPS mandates with renewable energy generation. ${ }^{1}$ Overall, states achieved a compliance rate (assuming use of renewable energy to meet targets as opposed to paying alternative compliance payments) of $94 \%$ in 2006, on a weighted-average basis. In several states, renewable energy was used to achieve only a portion of compliance, such as in Massachusetts (74\%), New York (52\%), Nevada (39\%), and Arizona (25\%) (Wiser and Barbose 2008).

This report examines the balance between the demand and supply of new renewable electricity in the United States on a regional basis through 2015. It expands on the 2007 NREL study (Swezey et al. 2007) that assessed the supply and demand balance on a national basis. As with the earlier study, this analysis relies on estimates of demand for renewable energy generation needed to meet existing state RPS policies, as well as demand by consumers who voluntarily purchase renewable energy. However, it does not address demand by utilities that may procure renewables for cost-effectiveness because of the difficulty in estimating such demand. The analysis examines two supply scenarios:

\footnotetext{
${ }^{1}$ Some states allow obligated entities to pay an alternative compliance payment (ACP) to achieve compliance, rather than procuring renewable energy. The authors defined compliance strictly by the retirement of RECs and did not account for states in which ACPs are an accepted means of compliance.
} 
1) a business as usual (BAU) scenario based on current growth rates in renewable energy supply in each region and 2) a market-based scenario that differs only in an assumed higher overall level of wind energy development nationally (based on estimates from BTM Consult and referred to as "high wind" case). Key uncertainties are discussed and the supply-demand balances are presented for each region through 2015. Finally, the paper discusses the implications of the regional supply-demand balances in terms of barriers to development, interregional trading opportunities, and the need for new transmission to facilitate interregional transfers. 


\section{Assumptions and Methodology}

This analysis compares estimates of regional renewable energy supplies to estimates of regional demand for renewable energy from existing state RPS policies and voluntary markets through 2015. This section discusses the general methodology and assumptions used in the regional analysis. The following sections present additional details on the assumptions used to calculate available renewable energy supplies and demand from RPS and voluntary markets.

\section{Focus on New Renewable Energy Capacity}

This analysis focuses on "new" renewable energy generation that may be used to meet state RPS requirements and voluntary market demand. In this analysis, "new" is defined as renewable energy projects installed on or after January 1, 1997 - this matches the generally accepted definition of "new" for voluntary market purposes. ${ }^{2}$ Therefore, the projections developed here for both supply and demand focus on "new" renewables. While definitions of "new" renewables may vary among RPS requirements, most RPS policies were adopted after 1997 and were generally designed to support the development of new renewables. ${ }^{3}$ Many state mandates treat previously existing (e.g., pre-1997) renewable energy resources differently, and some states do not include them as eligible resources at all. A common threshold between "new" and "existing" capacity was established to represent the diverse state definitions.

As a practical matter, most recent (post-1990) renewable energy development in the United States has occurred since the late 1990s, after RPS mandates and voluntary markets began to take shape. Consequently, the further the analysis extends into the future, the less it matters precisely where the threshold between "new" and "existing" falls.

\section{Regional Breakdown}

The regional divisions used for this analysis are designed to reflect the ability of renewable energy generators to meet state RPS demand within the presumed constraints of power markets or electricity-deliverability requirements. The regions used here are drawn from two sources: regional transmission organization (RTO) control areas, and reliability regions used by the North American Electric Reliability Corporation (NERC), which can serve as a proxy for RTOs or power markets where they do not exist. ${ }^{4}$ Although every part of the country is in a NERC reliability region, large parts of the West

\footnotetext{
${ }^{2}$ This is a standard definition of both the Green-e renewable energy certification program (http://www.green-e.org/getcert_re_stan.shtml) and the EPA Green Power Partnership (http://epa.gov/greenpower/buygp/product.htm). Also, due to limitations of the source data, this report does not address repowered plants that may be eligible for RPS compliance or the voluntary market.

${ }^{3}$ Only three states adopted RPS policies prior to 1997, including Minnesota (1994), Arizona (1996), and Iowa (1983). Of these, Iowa's standard has already been met and does not contribute to the demand estimates in this analysis.

${ }^{4}$ An RTO combines all generating units into an integrated wholesale market that responds to real-time changes in regional demand. NERC regions are the geographical framework for reliability standards and contingency plans designed to prevent failure of the electrical grid.
} 
and the Southeast have no RTO. Furthermore, NERC regions are used because the national databases used to determine available renewable energy supplies identify specific plants by NERC region, not by RTO.

In this analysis, a region comprises a state or group of states whose combined area closely corresponds to the overlapping footprints of an RTO and a NERC region, or to the NERC region where no RTO is present. ${ }^{5}$ Figure 1 presents the regions that are used in this analysis. Data for individual units in these grouped states are processed according to a state and NERC region. In this analysis, demand and supply are considered a function of the region in which the state is located; in some cases, the region is defined as an individual state. Differences among state RPS policies regarding geographic requirements for renewable energy generation are not addressed in all cases, because some policies encourage or require in-state renewable energy development. Table 1 summarizes state RPS requirements for geographic eligibility of renewable energy resources (i.e., the location of eligible renewable energy generators or the need for eligible renewable energy generation to be delivered into the state or region).

Many RPS policies allow generation from within the RTO to meet the state renewable energy requirement. For example, the RPS for most states in the Mid-Atlantic region requires that renewable energy be delivered into the PJM Interconnection, meaning that out-of-state facilities can satisfy each state mandate as long as they deliver power to the RTO. Likewise, most states in New England require that the renewable energy used to meet the RPS requirements be generated within or delivered into the ISO New England, the region's independent system operator (ISO) and RTO. This is also partly the case in the Midwest, where many state RPS policies allow delivery of renewable generation in the Midwest ISO or PJM Interconnection. A few states in the Midwest, such as Illinois and Ohio, require or encourage some renewable energy to be generated within the state, but that level of specificity is not addressed in this analysis.

New York, Texas, and California - as well as Florida, Hawaii, and, Alaska - are treated as single-state regions in this analysis. Texas is treated separately because its RTO, the Electric Reliability Council of Texas (ERCOT), is largely not interconnected with the Eastern and Western Interconnections; in addition, the Texas RPS requires that the renewable energy capacity be built within Texas or be delivered with a dedicated transmission line into the state. New York has its own RTO. California also has its own RTO/ISO covering most of the state, and has a large RPS that requires delivery into the state. Alaska, Hawaii, and Florida are all treated as individual regions consistent with defined NERC regions. For all of these states, demand from the state RPS (if applicable) and estimates of voluntary market within the state are matched with supplies located in the state.

\footnotetext{
${ }^{5}$ In some cases, RTOs and NERC regions are not entirely congruent where a reliability region coexists with an RTO. For example, the PJM footprint does not exactly match ReliabilityFirst Corp. (RFC), the corresponding NERC region. In addition, RTOs and NERC regions do not necessarily align with state boundaries. In this analysis, we have defined regions along state boundaries that most closely match the footprint of the appropriate RTO or NERC region.
} 
Finally, Illinois and Montana are split among two regions. This was done because wind generators are interconnected with other states via two RTOs.

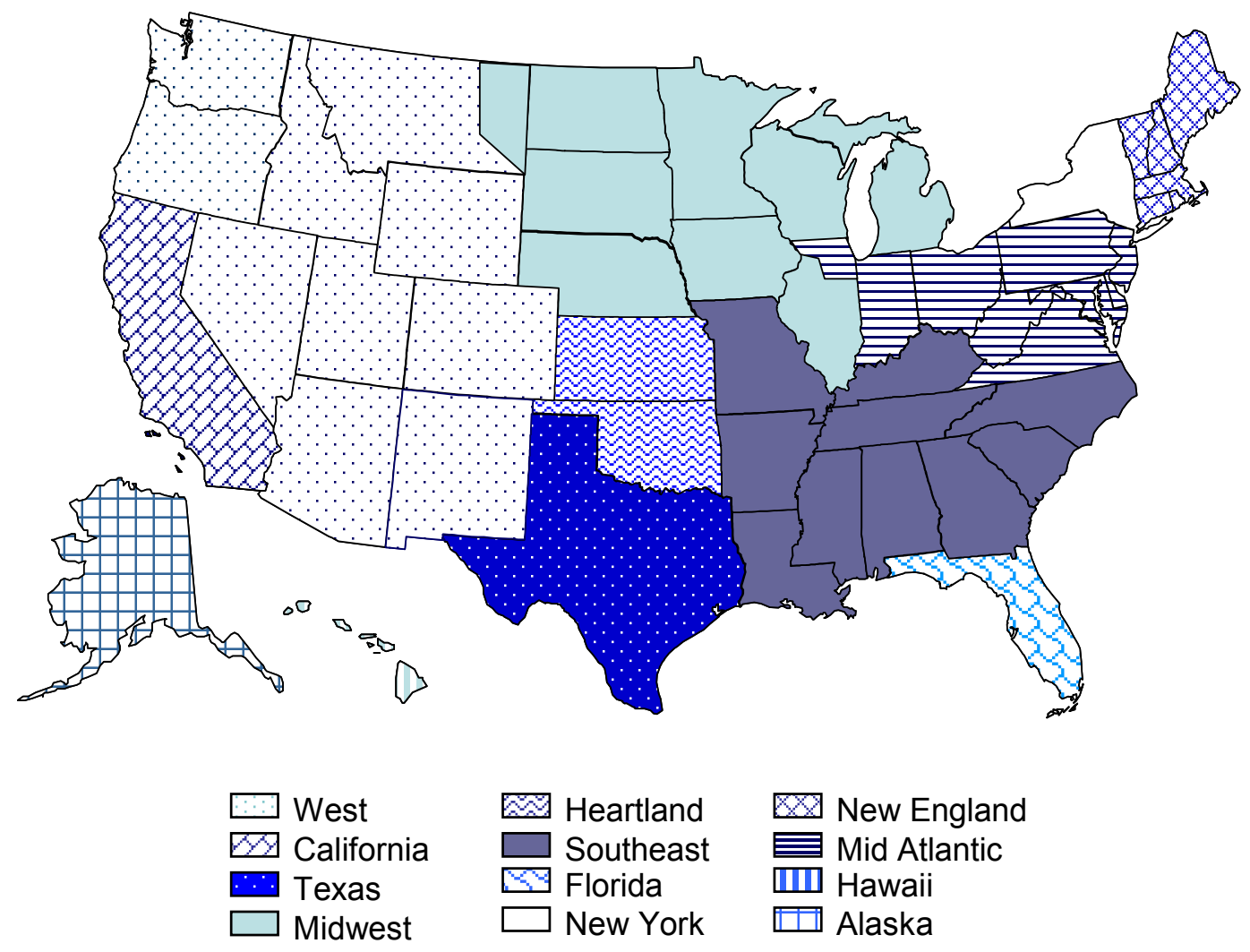

Figure 1. Supply and demand regions as defined in the analysis (modified NERC regions or ISOs) 
Table 1. Geographic Eligibility Requirements for States with RPS

\begin{tabular}{|c|c|c|}
\hline State & $\frac{\text { Region in }}{\text { Analysis }}$ & Geographic Eligibility \\
\hline AZ & West & Electricity delivery required to state or to load-serving entity (LSE) \\
\hline $\mathrm{CA}$ & California & Electricity delivery required to state or to LSE \\
\hline $\mathrm{CO}$ & West & No restriction on eligibility, but in-state is encouraged with mulitipliers \\
\hline CT & New England & Renewable facilities must be located in New England ISO (NE ISO) or adjacent control areas \\
\hline $\mathrm{DC}$ & Mid Atlantic & Renewable facilities must be located in PJM Interconnection or adjacent states \\
\hline $\mathrm{DE}$ & Mid Atlantic & Generators outside of PJM must deliver electricity to the region \\
\hline $\mathrm{HI}$ & Hawaii & In-state required \\
\hline IA & Midwest & In-state required \\
\hline IL & $\begin{array}{l}\text { Midwest/ Mid } \\
\text { Atlantic }\end{array}$ & $\begin{array}{l}\text { In-state generation encouraged, if not cost-effective, generation from adjacent states, then the } \\
\text { whole region can be accepted }\end{array}$ \\
\hline MA & New England & Renewable facilities must be located within NE ISO or adjacent control areas \\
\hline MD & Mid Atlantic & Renewable facilities must be located in PJM \\
\hline ME & New England & Generators outside of NE ISO must deliver electricity to the region \\
\hline MI & Midwest & $\begin{array}{l}\text { Unbundled RECs or electricity must be generated in-state or within the utility's service territory, } \\
\text { some exceptions apply }\end{array}$ \\
\hline MN & Midwest & Generators must be within Midwest Renewable Tracking System (M-RETS) \\
\hline $\mathrm{MO}$ & Southeast & No restriction on eligibility, but in-state is encouraged with mulitipliers \\
\hline MT & $\begin{array}{l}\text { West/ } \\
\text { Midwest }\end{array}$ & Electricity delivery required to state or to LSE \\
\hline NC & Southeast & $\begin{array}{l}\text { Up to } 25 \% \text { of the RECs needed for compliance can be met with unbundled RECs from outside } \\
\text { state. Rest must be in-state or delivered to LSE }\end{array}$ \\
\hline $\mathrm{NH}$ & New England & Renewable facilities must be located within NE ISO or adjacent control areas \\
\hline NJ & Mid Atlantic & $\begin{array}{l}\text { Generators must be within or deliver electricity to the region; resources outside of PJM must be } \\
\text { "new" }\end{array}$ \\
\hline NM & West & Electricity delivery required to state or to LSE \\
\hline NV & West & Electricity delivery required to state or to LSE by direct transmission \\
\hline NY & New York & $\begin{array}{l}\text { Electricity delivery required to state or to LSE, subject to strict hourly scheduling to the state. } \\
\text { Strong preference for in-state resources }\end{array}$ \\
\hline $\mathrm{OH}$ & Mid Atlantic & Electricity delivery required to state or LSE, at least $50 \%$ must be generated in-state \\
\hline OR & West & $\begin{array}{l}\text { Unbundled RECs must be generated in WECC. Electricity must be generated within the U.S. and } \\
\text { delivered to LSE }\end{array}$ \\
\hline $\mathrm{PA}$ & Mid Atlantic & Renewable facilities must be located in PJM or in Midwest ISO for some LSEs \\
\hline RI & New England & Renewable facilities must be located within NE ISO or adjacent control areas \\
\hline TX & Texas & Electricity delivery required to state or to LSE by direct transmission \\
\hline WA & West & Generators outside of the Pacific Northwest must deliver electricity to the state \\
\hline WI & Midwest & state or to LSE; facilities must b \\
\hline
\end{tabular}

Source: Wiser and Barbose 2008, Bricker and Eckler 2008 


\section{Supply-Side Analysis}

\section{Estimates of Current Installed New Capacity (Through 2006)}

To estimate current renewable energy supplies, the analysis relied primarily on data from the U.S. Energy Information Administration (EIA), which collects and reports data on net summer capacity and electricity generation from renewable energy sources annually. ${ }^{6}$ For 2006, EIA estimates that non-hydro renewable energy sources total 28,721 MW of net summer capacity (EIA 2008a). ${ }^{7}$ However, the focus of this analysis was supply from new renewable energy-generating projects, which are generally defined as projects that came online on or after January 1, 1997, as discussed earlier. Therefore, the EIA data was filtered to identify capacity installed after 1997; Table 2 shows that $12,150 \mathrm{MW}$ of "new" renewable capacity was online in $2006 .^{8}$

In this analysis, the EIA capacity estimates are supplemented with data from the U.S. Environmental Protection Agency (EPA), the American Wind Energy Association (AWEA), and the Interstate Renewable Energy Council (IREC) to derive estimates of new renewable electricity availability. Wind capacity numbers were calculated from AWEA's project database, which is frequently updated with information on wind energy installations. For landfill gas, the U.S. EPA's Landfill Methane Outreach Program (LMOP) data were used for their comprehensiveness, because plants smaller than $1 \mathrm{MW}$ are not required to report data to EIA. ${ }^{9}$ Because many solar photovoltaic (PV) systems also fall under the $1 \mathrm{MW}$ reporting threshold, this analysis relies on PV capacity estimates from IREC, which are based on data collected from states and are more comprehensive than EIA solar PV data (Sherwood 2008).

The inclusion of hydropower and municipal solid waste (MSW) raises a number of issues for this analysis because these sources are not often included in "green power" definitions, although they may be acceptable for RPS compliance in some states. Early market definitions distinguished between small hydro (no more than $30 \mathrm{MW}$ of nameplate capacity) and large hydro (larger than $30 \mathrm{MW}$ ). More recently, the green power industry has differentiated hydropower plants by their environmental impacts, such as "low-impact" hydropower. ${ }^{10}$ For this analysis, only new hydropower generation from plants below the $30 \mathrm{MW}$ capacity threshold were included. As for MSW, the EIA

\footnotetext{
${ }^{6}$ The Energy Information Administration "EIA Form 860 - Annual Electric Generator Report" compiles information about generators at electric power plants. "EIA Form 906 Monthly Utility Power Plant Database" and "Form 920 Combined Heat and Power Plant Report" collects monthly and annual data on electricity generation and fuel consumption at the power plant and prime mover level for utility and nonutility electric power generators. EIA also collects data through "Form 767 - Annual Steam-Electric Plant Operation and Design Data."

${ }^{7}$ For renewables, EIA's summary reports distinguish between "conventional hydropower" and "other renewables." For this analysis, we are most interested in the "other renewables" resource category because (with some exceptions) "conventional hydropower" is generally excluded from certification for voluntary market purchases and from eligibility to meet state renewable portfolio standards.

${ }^{8}$ For 2006, EIA estimates that non-hydro renewable energy sources supplied 96,423 gigawatt hours (GWh) of electricity. In Table 5, we estimate that 37,068 GWh of "new" renewable energy was generated in 2006.

${ }^{9}$ See EIA reporting requirements at http://www.eia.doe.gov/cneaf/electricity/page/forms.html and http://www.epa.gov/lmop/

${ }^{10}$ See Low Impact Hydropower Institute, URL: http://lowimpacthydro.org/, accessed September 24, 2007.
} 
data showed only 18.5 MW of new capacity additions from 1997 to 2004, and it was included because it does not significantly affect the overall results.

For plants with boilers that can co-fire biomass and fossil fuels, the amount of eligible biomass capacity was estimated based on the fraction of biomass fuel used in the facility. The plant's total capacity was multiplied by the fraction of total annual heat input provided by biomass fuels, as reported to EIA.

Table 2 summarizes the cumulative quantity of "new" renewable energy capacity by resource. Table 3 shows the installed new capacity by the regions defined in this analysis.

Table 2. Cumulative "New" Renewable Energy Capacity by Technology through 2006 (MW)

\begin{tabular}{|l|c|c|c|}
\hline & $\mathbf{2 0 0 4}$ & $\mathbf{2 0 0 5}$ & $\mathbf{2 0 0 6}$ \\
\hline Biomass & 649 & 680 & 785 \\
\hline Geothermal & 129 & 164 & 217 \\
\hline Hydropower & 271 & 301 & 311 \\
\hline Landfill Gas & 561 & 611 & 698 \\
\hline MSW & 19 & 19 & 38 \\
\hline Solar PV & 119 & 160 & 236 \\
\hline Wind & 5,036 & 7,442 & 9,866 \\
\hline \hline Total & 6,780 & 9,380 & 12,150 \\
\hline
\end{tabular}

Note: Numbers may not sum due to independent rounding

Table 3. Cumulative "New" Renewable Energy Capacity by Region through 2006 (MW)

\begin{tabular}{|l|c|c|c|}
\hline & $\mathbf{2 0 0 4}$ & $\mathbf{2 0 0 5}$ & $\mathbf{2 0 0 6}$ \\
\hline Midwest & 1,555 & 2,086 & 2,415 \\
\hline New England & 109 & 136 & 148 \\
\hline New York & 106 & 256 & 442 \\
\hline Mid Atlantic & 582 & 580 & 702 \\
\hline Heartland & 290 & 739 & 899 \\
\hline Southeast & 377 & 383 & 460 \\
\hline Florida & 104 & 80 & 102 \\
\hline California & 797 & 920 & 1,245 \\
\hline West & 1,519 & 2,143 & 2,896 \\
\hline Texas & 1,315 & 2,010 & 2,756 \\
\hline Alaska & 11 & 13 & 23 \\
\hline Hawaii & 20 & 30 & 64 \\
\hline \hline Total & 6,780 & 9,380 & 12,150 \\
\hline
\end{tabular}

Note: Numbers may not sum due to independent rounding 


\section{Estimates of Generation from Installed Facilities (Through 2006)}

After determining eligible new capacity, the analysis estimated the generation output of the renewable energy facilities. Because EIA is not comprehensive in reporting the generation output from the renewable energy plants, weighted-average capacity factors for each resource (with some exceptions) were calculated for plants for which generation was reported. These capacity factors were then applied to plants with unreported generation to estimate total generation for each renewable energy fuel type. ${ }^{11}$ Because black liquor and solid wood waste are often combusted in the same facility, a single capacity factor was used.

For wind, solar thermal electric, and solar PV, capacity factors were developed from data sources other than EIA. Regional wind energy capacity factors were derived from the Department of Energy's (DOE's) annual report on the wind market, which provides regional capacity factors based on measured data (Wiser and Bolinger 2007, 2008). These factors reflect the variation in generation output of wind facilities by the year of installation and region. Table 4 presents a sample of these capacity factors, applied to the regions defined in this report. ${ }^{12}$ PV capacity factors are based on NREL data and assume a 10-degree tilt and due-south orientation (Denholm 2008); they generally range from $12 \%$ to $18 \%$, with a lower capacity factor ( $8 \%$ ) for Alaska. The analysis assumes a $35 \%$ capacity factor for new concentrating solar power (CSP) thermal plants installed in future years to reflect a mix of plants with and without storage.

Table 4. Wind Capacity Factors for Study Regions

\begin{tabular}{|l|c|c|c|c|c|c|c|c|c|c|}
\hline $\begin{array}{l}\text { Year of } \\
\text { Installation }\end{array}$ & Midwest & $\begin{array}{c}\text { New } \\
\text { England }\end{array}$ & New York & $\begin{array}{c}\text { Mid } \\
\text { Atlantic }\end{array}$ & Heartland & Southeast & California & West & Texas & Hawaii \\
\hline $1998-99$ & $26 \%$ & $24 \%$ & $22 \%$ & $22 \%$ & $28 \%$ & $22 \%$ & $30 \%$ & $33 \%$ & $29 \%$ & - \\
\hline $2000-01$ & $29 \%$ & $24 \%$ & $22 \%$ & $23 \%$ & $32 \%$ & $22 \%$ & $36 \%$ & $29 \%$ & $31 \%$ & - \\
\hline $2002-03$ & $29 \%$ & $24 \%$ & $29 \%$ & $26 \%$ & $34 \%$ & $29 \%$ & $31 \%$ & $30 \%$ & $35 \%$ & - \\
\hline $2004-05$ & $36 \%$ & $24 \%$ & $27 \%$ & $29 \%$ & $38 \%$ & $27 \%$ & $36 \%$ & $37 \%$ & $37 \%$ & - \\
\hline 2006 & $37 \%$ & $22 \%$ & $29 \%$ & $30 \%$ & $41 \%$ & $29 \%$ & $37 \%$ & $35 \%$ & $30 \%$ & $45 \%$ \\
\hline \hline $\begin{array}{l}\text { Average } \\
2002-2006\end{array}$ & $34 \%$ & $23 \%$ & $29 \%$ & $28 \%$ & $37 \%$ & $29 \%$ & $35 \%$ & $34 \%$ & $34 \%$ & $45 \%$ \\
\hline
\end{tabular}

Note: Original wind capacity factors are applied to regions defined in this analysis. The supply projections use the average wind capacity factors between 2002 and 2006. The Wiser et al. report does not include projects in Alaska, due to a small sample size.

Table 5 presents estimates of the generation output from new renewable energy facilities for 2004-2006 by resource. It is important to note that wind energy represents nearly three-quarters of the total generation from new facilities. New renewable energy generation totaled 21 terawatt hours (TWh) in 2004, $30 \mathrm{TWh}$ in 2005, and $37 \mathrm{TWh}$ in 2006. Table 6 presents generation from new renewable energy facilities by the regions defined in this analysis.

\footnotetext{
${ }^{11}$ Generation was estimated using the following weighted average capacity factors: Agricultural Crop Byproducts: 0.31; Black liquor: 0.49; Other Biomass Solid: 0.33; Other Biomass Gases: 0.17; Other Biomass Liquids .49; Geothermal: 0.96; Landfill gas: 0.68; Municipal solid waste: 0.3. Hydroelectric: 0.26: Small hydroelectric $(\leq 30 \mathrm{MW}): 0.4$. These capacity factors were estimated using available capacity and generation data from EIA forms 860 and 906/920.

${ }_{12}$ The regions used in the DOE study are not the same as the regions used here. However, this analysis uses the appropriate capacity factors for each of the regions specified here.
} 
Table 5. Renewable Energy Generation by Technology, 2004-2006 (GWh)

\begin{tabular}{|l|c|c|c|}
\hline & $\mathbf{2 0 0 4}$ & $\mathbf{2 0 0 5}$ & $\mathbf{2 0 0 6}$ \\
\hline Biomass & 2,469 & 2,657 & 3,057 \\
\hline Geothermal & 1,082 & 1,375 & 1,815 \\
\hline Hydropower & 958 & 1,066 & 1,099 \\
\hline Landfill Gas & 3,334 & 3,631 & 4,149 \\
\hline MSW & 48 & 48 & 99 \\
\hline Solar PV & 98 & 128 & 192 \\
\hline Wind & 13,351 & 20,923 & 26,657 \\
\hline \hline Total & 21,340 & 29,828 & 37,068 \\
\hline
\end{tabular}

Note: Figures may not sum due to independent rounding.

Table 6. Renewable Energy Generation by Region, 2004-2006 (GWh)

\begin{tabular}{|l|c|c|c|}
\hline & $\mathbf{2 0 0 4}$ & $\mathbf{2 0 0 5}$ & $\mathbf{2 0 0 6}$ \\
\hline Midwest & 4,278 & 5,586 & 6,853 \\
\hline New England & 485 & 629 & 654 \\
\hline New York & 322 & 688 & 1,134 \\
\hline Mid Atlantic & 2,330 & 2,645 & 3,009 \\
\hline Heartland & 833 & 2,318 & 2,390 \\
\hline Southeast & 1,522 & 1,588 & 1,903 \\
\hline Florida & 391 & 327 & 408 \\
\hline California & 2,712 & 3,035 & 4,047 \\
\hline West & 4,666 & 6,891 & 7,573 \\
\hline Texas & 3,698 & 5,988 & 8,799 \\
\hline Alaska & 38 & 46 & 73 \\
\hline Hawaii & 65 & 87 & 225 \\
\hline \hline Total & 21,340 & 29,828 & 37,068 \\
\hline
\end{tabular}

Note: Figures may not sum due to independent rounding.

\section{Supply Projection Methodology (2007-2015)}

In most cases, data on installed renewable energy capacity are available only through 2006, except in a few instances where 2007 and 2008 data exist. This analysis estimates future renewable energy capacity for 2007 through 2015 using annual growth rates or other methodologies depending on the resource. In some cases, future capacity was estimated using information on plants under construction, under contract, or in development, derated depending on the stage of development of the project to reflect uncertainty. The specific methodologies and assumptions for each resource are described below.

\section{Wind}

For wind, installed capacity data were available from AWEA through 2008. The estimate for 2008 relied on AWEA's preliminary estimates of installed wind capacity by region for 2008 (AWEA 2009). 
Wind energy capacity projections begin in 2009 and extend through 2015. This analysis presents two projection scenarios: 1) a business as usual (BAU) scenario based solely on current trends observed through 2008, and 2) a market forecast scenario that is a national high wind scenario (referred to as the "high wind" case) based on a market analysis by BTM Consult, an independent consulting firm from Denmark that specializes in renewable energy services, particularly wind energy. Two estimates of future wind capacity were prepared to represent the large fraction of new renewable energy generation currently installed and its rapid growth. As the dominant renewable technology, it has the most significant impact on the analysis.

The BAU case is a trend analysis using historical data from 1999 to 2008 for total installed wind capacity. The forecast applies an ordinary least squares regression to identify the linear trend, representing a simple continuation of observed growth with no assumption about new state RPS policies, other future policy changes, or systemic disturbances. The model accounts for the observed acceleration in installed capacity that began after 2005. This analysis uses the lower bound of the model's $95 \%$ confidence interval, rather than the mean estimates. ${ }^{13}$ This makes the projection a reasonable worstcase scenario based on extending historical trends. An important caveat is that the forecast assumes transmission infrastructure will be built to meet new wind capacity additions, as it has in the past. If transmission expansion fails to keep pace, these forecasts will overestimate the amount of wind power that will be available in the future.

The market forecast for 2009 and beyond - the high wind case - assumes future capacity additions based on a forecast by BTM Consult (BTM 2008). The BTM Consult projection assumes 6,500 MW of new incremental wind capacity installed in the United States in 2009 and assumes the addition of 10,500 MW of new incremental wind energy capacity in 2015. Because the BTM projections are only available nationally, and are not broken out regionally, wind energy capacity was apportioned by region using modeling results published in a recent study by DOE (DOE 2008) that presents a scenario of $20 \%$ wind energy penetration by $2030 .{ }^{14}$ The DOE $20 \%$ wind study is an optimization analysis that estimates where wind energy would be installed in the United States to most costeffectively generate $20 \%$ of the nation's electricity demand from wind energy by 2030 (DOE 2008). Figure 2 compares the wind energy capacity estimated through 2015 under the BAU scenario, the high wind case, and the DOE $20 \%$ wind study. Notably, both of the projections presented here are higher than the DOE $20 \%$ wind study up to 2012; but, by 2015 , both the high wind case and the DOE projections are well above the BAU projection.

\footnotetext{
${ }^{13}$ The $95 \%$ confidence interval, which is bounded by lower and upper bound estimates and calculated using the standard error of the mean, is expected to include the true mean $95 \%$ of the time.

${ }^{14}$ To apportion the capacity among the regions assumed here, we used the 2008 NREL Regional Energy Deployment System (ReEDS) model output data, which are the basis of the $20 \%$ wind study.
} 


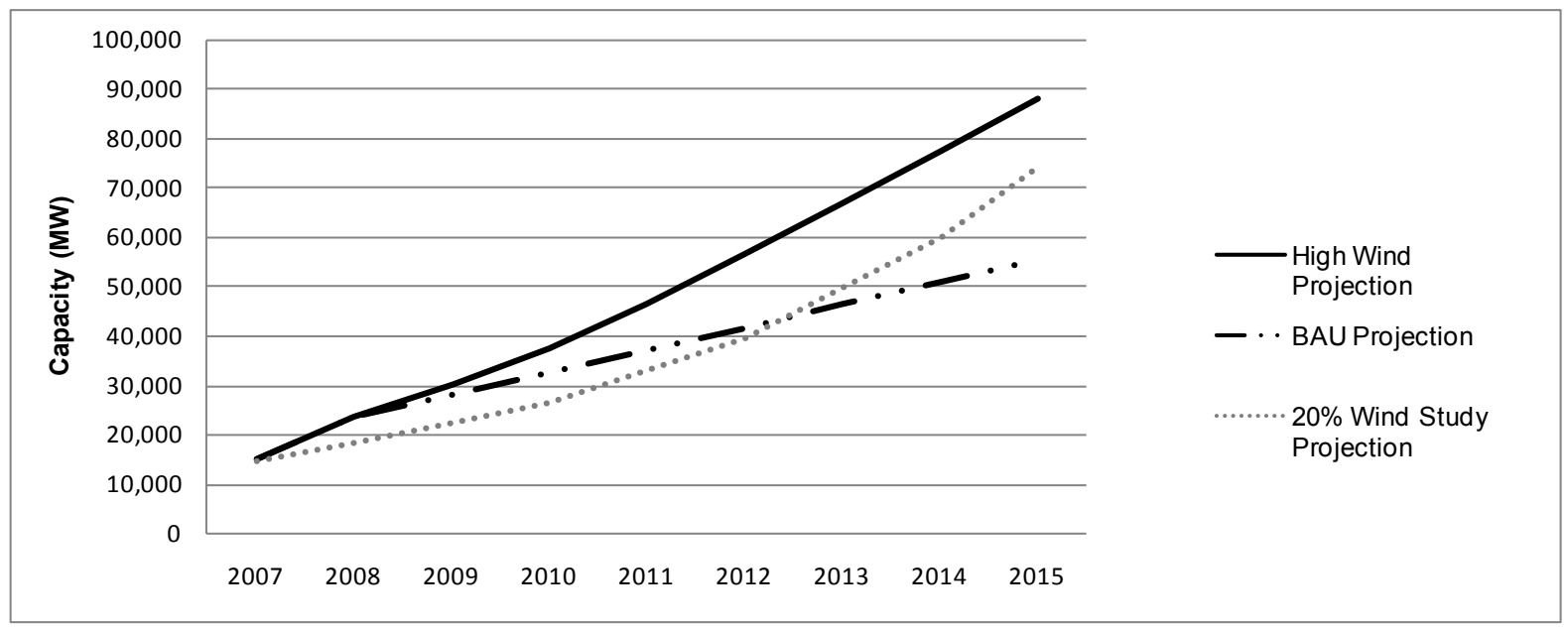

Figure 2. Wind supply projections compared to $20 \%$ wind scenario

\section{Biomass, MSW, Hydropower}

For biomass, MSW, and hydropower, projections of future capacity are based on assumptions of constant annual growth. The compound annual growth rates were calculated based on 2004-2006 EIA data. For biomass, separate growth rates were used for each of the EIA-reported biomass resource types. ${ }^{15}$ Growth rates were modified in three instances. The growth rate for "other biomass liquid" was assumed to be the same as that for black liquor, due to small-sample irregularities. For "other biomass solids" and "other biomass gases," the analysis assumes no growth rather than the decrease shown over the sample period.

\section{Landfill Gas}

Data on installed landfill gas-generating capacity is available from the U.S. EPA through 2007. From 2008 through 2010, landfill gas capacity is assumed to grow at a constant annual growth rate (14\% annually) based on historic levels. For each year from 20112015 , the analysis assumed 85 MW of new capacity was added each year, consistent with the average amount of capacity added annually from 2000 to 2007 (Goldstein 2008).

\section{Geothermal}

Geothermal projections are based on announced projects identified by the Geothermal Energy Association (GEA) (see Appendix A). The GEA categorizes projects into four phases based on their development status. Only projects in the third and fourth phases ${ }^{16}$ (those nearest to completion) were included in these projections; capacity in very early development stages was not specifically considered because of the uncertainty in these projects. Projects under construction (in Phase Four) were assumed to come online in

\footnotetext{
${ }^{15}$ The following EIA biomass resource types were included in the analysis: agricultural biomass, black liquor, other biogas, other bio-liquid, other biomass solids, wood liquids, and wood solids.

${ }^{16}$ Projects in Phase Four are those that are under construction or where production drilling is under way. Phase Three projects are defined as those securing power purchase agreements (PPA) and final permits. Phase Two projects are those where exploratory drilling and confirmation is being done and where a PPA is not secured. Phase One projects are those in which developers are identifying the site, conducting initial exploration drilling, and securing the right to the resource.
} 
2009 at the full reported capacities. The total capacity of projects under contract (but not under construction) was spread evenly over the years 2010-2012, with the assumption that a total of $75 \%$ of the Phase Three capacity would come online (a derate of $25 \%$ ). To estimate additional capacity that is in early stages of planning or has not yet been announced, capacity is assumed to grow in 2013-2015 based on a linear trend extrapolated from capacity installed in 2009-2012. All projected capacity is assumed to occur in California or the Western Electricity Coordinating Council (WECC) region, consistent with the list of announced plants from GEA.

\section{Solar Photovoltaics}

State-specific PV capacity data for 2007 (and earlier) was obtained from the Interstate Renewable Energy Council (Sherwood 2008). PV projections (for 2008-2015) are based on assumptions that vary by state. States with significant PV capacity and without an RPS solar set-aside ${ }^{17}$ were assumed to grow based on historical installation rates. The analysis used compound annual growth rates based on 2004-2007 data from IREC (Sherwood 2008). For states that have an RPS with a solar set-aside, the analysis assumes that the solar targets are met, which is arguably an optimistic assumption, but may be feasible given the long-term extension of the federal investment tax credits (ITC) for solar and the ability for utilities to take advantage of these incentives. On a generation basis, the contributions from solar are relatively small over the period of the analysis (roughly $5 \%$ of generation under the scenarios), so this assumption does not materially affect the regional results. Data on the size of the solar set-asides was derived from Wiser and Barbose (2008).

For California, PV capacity is assumed to grow at the historical growth rate (41\%) in 2008. From 2009-2015, the analysis assumed California was on track to meet the California Solar Initiative, which has established a goal of installing 3,000 MW of new solar capacity by $2017 .{ }^{18}$ California is assumed to meet the goal linearly with equal capacity additions in each year during that period. Massachusetts is assumed to meet its goal of installing approximately $27 \mathrm{MW}$ between 2008 and 2012 linearly, and a linear trend is used to project new capacity from 2013 to $2015 .{ }^{19}$

\footnotetext{
${ }^{17}$ An RPS set-aside is a provision within an RPS that calls for a certain fraction of electricity to be obtained from solar resources. Some states have specific requirements that a certain portion or all of the solar come from distributed systems; whereas others allow for utility-scale solar systems, which can include solar thermal electric systems.

${ }^{18}$ If the historical growth rate was applied through 2015, it would have resulted in more than 4,000 MW of capacity. Because the growth rate was on track to meet the initiative, we assumed California would meet the program goals. For more information on the California Solar Initiative, see http://www.gosolarcalifornia.org/csi/index.html.

${ }^{19}$ In 2008, the Commonwealth of Massachusetts announced a program called Commonwealth Solar, designed to provide incentives for approximately $27 \mathrm{MW}$ of new PV in the state between 2008-2012. The $\$ 68$ million program is funded through a combination of renewable public benefit funds and RPS alternative compliance payments. For more information, see http://www.masstech.org/SOLAR/, accessed January 31, 2009.
} 


\section{Concentrating Solar Power (CSP)}

Solar thermal projections are based on planned projects identified in Wiser and Barbose (2008), the Prometheus Institute, and the Solar Energy Industries Association (SEIA)

(2007) (see the projects in Appendix A). In addition, one other project not listed in these reports was identified. Solar thermal projects were categorized based on their

development status, as either contracted or in the feasibility stage, or announced or in the early planning stages. Projects in the contracted/feasibility phase were derated $40 \%$ to account for uncertainties associated with permitting, transmission availability, and other nonproject-specific variables. A higher derate factor is used for CSP than for geothermal projects because the CSP industry is young and there are more speculative projects proposed. Projects in the announced/planning phase were derated $70 \%$ due to the greater uncertainties with project completion. Individual plants (derated) were assumed to begin operation in the announced operational year (whenever available) or were estimated using the best available information. One plant that was expected to enter commercial operation in 2009 was pushed back to 2010 due to known delays. Estimates for plants for which an operation date was unknown were spread evenly over 2011-2013. Estimated capacity installed in 2014 and 2015 were based on linear trend projections from 20102013.

\section{Supply Estimates, by Technology and Region}

Table 7 presents projections (and some actual data for 2007 and 2008, as explained above) of the cumulative new capacity by resource for 2007-2015. Both the BAU and high wind case projections are presented, with the resulting totals. New renewable capacity would reach about $70 \mathrm{GW}$ in 2015 under the BAU case and more than $100 \mathrm{GW}$ under the high wind case. Note that this table includes new renewable energy capacity only - the pre-1997 capacity is not included.

Table 7. Projected Cumulative Installed New Renewable Energy Capacity by Resource, 2007-2015 (MW)

\begin{tabular}{|l|c|c|c|c|c|c|c|c|c|}
\hline & $\mathbf{2 0 0 7}$ & $\mathbf{2 0 0 8}$ & $\mathbf{2 0 0 9}$ & $\mathbf{2 0 1 0}$ & $\mathbf{2 0 1 1}$ & $\mathbf{2 0 1 2}$ & $\mathbf{2 0 1 3}$ & $\mathbf{2 0 1 4}$ & $\mathbf{2 0 1 5}$ \\
\hline Biomass & 881 & 992 & 1,120 & 1,267 & 1,437 & 1,633 & 1,861 & 2,125 & 2,431 \\
\hline Geothermal & 217 & 217 & 641 & 778 & 915 & 1,053 & 1,190 & 1,326 & 1,463 \\
\hline Hydro & 333 & 356 & 382 & 409 & 438 & 469 & 503 & 539 & 577 \\
\hline Landfill Gas & 849 & 974 & 1,119 & 1,284 & 1,369 & 1,454 & 1,539 & 1,624 & 1,709 \\
\hline MSW & 53 & 75 & 107 & 151 & 213 & 302 & 427 & 603 & 853 \\
\hline Solar - PV & 361 & 602 & 1,016 & 1,489 & 1,995 & 2,593 & 3,182 & 3,841 & 4,704 \\
\hline Solar - CSP & 65 & 65 & 66 & 502 & 1,074 & 1,761 & 1,935 & 2,565 & 3,063 \\
\hline BAU Wind & 15,142 & 23,503 & 28,054 & 32,604 & 37,155 & 41,611 & 46,256 & 50,807 & 55,358 \\
\hline High Wind & 15,142 & 23,503 & 30,003 & 37,503 & 46,503 & 56,504 & 67,004 & 77,504 & 88,004 \\
\hline \hline Total - BAU & 17,901 & 26,786 & 32,504 & 38,485 & 44,597 & 50,877 & 56,893 & 63,430 & 70,158 \\
\hline $\begin{array}{l}\text { Total - High } \\
\text { Wind }\end{array}$ & 17,901 & 26,786 & 34,454 & 43,384 & 53,945 & 65,769 & 77,640 & 90,127 & 102,805 \\
\hline
\end{tabular}

Tables 8 and 9 present the new renewable energy capacity projections by region under the BAU case and the high wind case, respectively. While the high wind case assumes more wind capacity is installed nationally over the time period considered, the allocation of capacity among regions is based on the assumptions in the NREL Regional Energy Deployment System (ReEDS) model. In the BAU case, the linear trends are calculated 
for each region, based on historic installations in the particular region. It is interesting to note that as a result of the different methods for allocating wind across regions in the two scenarios, the high wind case shows slightly less renewable energy capacity in some regions (e.g., Texas and the Midwest) in some years than the BAU case.

Table 8. Projected Cumulative Installed New Renewable Energy Capacity by Region: Business as Usual Case, 2007-2015 (MW)

\begin{tabular}{|l|c|c|c|c|c|c|c|c|c|}
\hline & $\mathbf{2 0 0 7}$ & $\mathbf{2 0 0 8}$ & $\mathbf{2 0 0 9}$ & $\mathbf{2 0 1 0}$ & $\mathbf{2 0 1 1}$ & $\mathbf{2 0 1 2}$ & $\mathbf{2 0 1 3}$ & $\mathbf{2 0 1 4}$ & $\mathbf{2 0 1 5}$ \\
\hline Midwest & 3,959 & 7,075 & 8,796 & 10,523 & 12,235 & 13,950 & 15,666 & 17,386 & 19,110 \\
\hline New England & 204 & 261 & 322 & 392 & 458 & 531 & 607 & 693 & 775 \\
\hline New York & 520 & 937 & 1,024 & 1,112 & 1,198 & 1,285 & 1,373 & 1,463 & 1,554 \\
\hline Mid Atlantic & 1,049 & 1,601 & 1,924 & 2,312 & 2,707 & 3,167 & 3,698 & 4,329 & 5,140 \\
\hline Heartland & 1,053 & 1,523 & 1,639 & 1,756 & 1,872 & 1,988 & 2,105 & 2,221 & 2,337 \\
\hline Southeast & 523 & 753 & 832 & 929 & 1,047 & 1,222 & 1,364 & 1,535 & 1,824 \\
\hline Florida & 118 & 131 & 145 & 160 & 173 & 187 & 202 & 218 & 235 \\
\hline California & 1,398 & 1,645 & 2,262 & 3,152 & 4,089 & 5,134 & 5,863 & 6,917 & 7,866 \\
\hline West & 4,578 & 5,584 & 6,747 & 7,797 & 8,934 & 9,993 & 11,060 & 12,179 & 13,291 \\
\hline Texas & 4,386 & 7,159 & 8,691 & 10,225 & 11,752 & 13,280 & 14,808 & 16,336 & 17,865 \\
\hline Alaska & 25 & 28 & 30 & 32 & 35 & 37 & 40 & 43 & 46 \\
\hline Hawaii & 87 & 88 & 91 & 94 & 97 & 102 & 106 & 110 & 114 \\
\hline \hline Total & 17,901 & 26,786 & 32,504 & 38,485 & 44,597 & 50,877 & 56,893 & 63,430 & 70,158 \\
\hline
\end{tabular}

Table 9. Projected Cumulative Installed New Renewable Energy Capacity by Region: High Wind Case, 2007-2015 (MW)

\begin{tabular}{|l|c|c|c|c|c|c|c|c|c|}
\hline & $\mathbf{2 0 0 7}$ & $\mathbf{2 0 0 8}$ & $\mathbf{2 0 0 9}$ & $\mathbf{2 0 1 0}$ & $\mathbf{2 0 1 1}$ & $\mathbf{2 0 1 2}$ & $\mathbf{2 0 1 3}$ & $\mathbf{2 0 1 4}$ & $\mathbf{2 0 1 5}$ \\
\hline Midwest & 3,959 & 7,075 & 8,186 & 9,468 & 11,350 & 13,441 & 15,683 & 17,929 & 20,418 \\
\hline New England & 204 & 261 & 360 & 477 & 636 & 815 & 999 & 1,194 & 1,548 \\
\hline New York & 520 & 937 & 1,088 & 1,262 & 1,452 & 1,663 & 1,818 & 1,975 & 2,217 \\
\hline Mid Atlantic & 1,049 & 1,601 & 2,045 & 2,600 & 3,312 & 4,147 & 5,061 & 6,075 & 7,292 \\
\hline Heartland & 1,053 & 1,523 & 1,759 & 2,030 & 2,651 & 3,341 & 4,610 & 5,879 & 7,490 \\
\hline Southeast & 523 & 753 & 888 & 1,050 & 1,256 & 1,530 & 1,847 & 2,193 & 2,737 \\
\hline Florida & 118 & 131 & 145 & 160 & 173 & 187 & 202 & 218 & 235 \\
\hline California & 1,398 & 1,645 & 3,471 & 5,769 & 7,838 & 10,247 & 11,924 & 14,021 & 15,686 \\
\hline West & 4,578 & 5,584 & 8,363 & 11,408 & 14,671 & 18,187 & 21,362 & 24,588 & 27,512 \\
\hline Texas & 4,386 & 7,159 & 8,004 & 8,979 & 10,382 & 11,940 & 13,813 & 15,685 & 17,249 \\
\hline Alaska & 25 & 28 & 30 & 33 & 36 & 40 & 44 & 48 & 52 \\
\hline Hawaii & 87 & 88 & 116 & 148 & 187 & 231 & 276 & 322 & 368 \\
\hline \hline Total & 17,901 & 26,786 & 34,454 & 43,384 & 53,945 & 65,769 & 77,640 & 90,127 & 102,805 \\
\hline
\end{tabular}

Table 10 presents projections of the generation from new renewable energy facilities by resource for 2007-2015. The BAU and high wind case projections are both presented, with the resulting totals. Note that the growth for non-wind renewables is the same for the two scenarios; the high wind case simply assumes greater wind energy development nationally. New renewable energy generation is expected to reach nearly $217 \mathrm{TWh}$ in 2015 under the BAU case and nearly 314 TWh under the high wind case. Tables 11 and 12 present the projected renewable energy generation by the regions defined in this analysis for the BAU and high wind cases. 
Table 10. Projected Renewable Energy Generation by Technology, 2007-2015 (GWh)

\begin{tabular}{|l|c|c|c|c|c|c|c|c|c|}
\hline & $\mathbf{2 0 0 7}$ & $\mathbf{2 0 0 8}$ & $\mathbf{2 0 0 9}$ & $\mathbf{2 0 1 0}$ & $\mathbf{2 0 1 1}$ & $\mathbf{2 0 1 2}$ & $\mathbf{2 0 1 3}$ & $\mathbf{2 0 1 4}$ & $\mathbf{2 0 1 5}$ \\
\hline Biomass & 3,491 & 3,956 & 4,493 & 5,113 & 5,830 & 6,659 & 7,621 & 8,736 & 10,030 \\
\hline Geothermal & 1,818 & 1,818 & 5,373 & 6,517 & 7,661 & 8,805 & 9,949 & 11,094 & 12,238 \\
\hline Hydro & 1,477 & 1,582 & 1,695 & 1,816 & 1,945 & 2,084 & 2,232 & 2,391 & 2,562 \\
\hline Landfill Gas & 5,047 & 5,794 & 6,652 & 7,638 & 8,143 & 8,648 & 9,154 & 9,659 & 10,165 \\
\hline MSW & 138 & 195 & 276 & 390 & 552 & 781 & 1,104 & 1,562 & 2,208 \\
\hline Solar - PV & 507 & 834 & 1,419 & 2,069 & 2,756 & 3,547 & 4,324 & 5,180 & 6,264 \\
\hline Solar - CSP & 199 & 199 & 202 & 1,540 & 3,294 & 5,398 & 5,934 & 7,863 & 9,392 \\
\hline BAU Wind & 45,082 & 69,660 & 83,124 & 96,589 & 110,053 & 123,229 & 136,981 & 150,445 & 163,909 \\
\hline High Wind & 45,082 & 69,660 & 88,937 & 111,178 & 137,847 & 167,478 & 198,737 & 229,997 & 261,080 \\
\hline \hline Total - BAU & 57,759 & 84,039 & 103,235 & 121,671 & 140,234 & 159,152 & 177,299 & 196,929 & 216,767 \\
\hline $\begin{array}{l}\text { Total - High } \\
\text { Wind }\end{array}$ & 57,759 & 84,039 & 109,047 & 136,260 & 168,028 & 203,401 & 239,056 & 276,480 & 313,937 \\
\hline
\end{tabular}

Table 11. Projected Renewable Energy Generation: Business as Usual Case, 2007-2015 (GWh)

\begin{tabular}{|l|c|c|c|c|c|c|c|c|c|}
\hline & $\mathbf{2 0 0 7}$ & $\mathbf{2 0 0 8}$ & $\mathbf{2 0 0 9}$ & $\mathbf{2 0 1 0}$ & $\mathbf{2 0 1 1}$ & $\mathbf{2 0 1 2}$ & $\mathbf{2 0 1 3}$ & $\mathbf{2 0 1 4}$ & $\mathbf{2 0 1 5}$ \\
\hline Midwest & 12,369 & 21,733 & 26,956 & 32,212 & 37,376 & 42,548 & 47,732 & 52,928 & 58,139 \\
\hline New England & 817 & 992 & 1,186 & 1,405 & 1,600 & 1,813 & 2,042 & 2,299 & 2,569 \\
\hline New York & 1,452 & 2,513 & 2,750 & 2,994 & 3,218 & 3,445 & 3,674 & 3,904 & 4,138 \\
\hline Mid Atlantic & 3,667 & 5,097 & 6,005 & 7,034 & 7,966 & 9,001 & 10,157 & 11,483 & 13,087 \\
\hline Heartland & 3,445 & 4,983 & 5,364 & 5,744 & 6,125 & 6,506 & 6,886 & 7,267 & 7,647 \\
\hline Southeast & 2,222 & 2,915 & 3,250 & 3,643 & 4,069 & 4,606 & 5,157 & 5,806 & 6,674 \\
\hline Florida & 486 & 542 & 604 & 674 & 726 & 781 & 838 & 900 & 965 \\
\hline California & 4,698 & 5,344 & 7,841 & 10,282 & 12,848 & 15,754 & 17,693 & 20,639 & 23,270 \\
\hline West & 14,624 & 17,598 & 22,306 & 26,048 & 30,047 & 33,810 & 37,599 & 41,547 & 45,480 \\
\hline Texas & 13,587 & 21,923 & 26,555 & 31,199 & 35,809 & 40,420 & 45,034 & 49,650 & 54,269 \\
\hline Alaska & 79 & 88 & 95 & 102 & 110 & 118 & 127 & 137 & 147 \\
\hline Hawaii & 311 & 313 & 324 & 333 & 341 & 350 & 360 & 370 & 381 \\
\hline \hline Total & 57,759 & 84,039 & 103,235 & 121,671 & 140,234 & 159,152 & 177,299 & 196,929 & 216,767 \\
\hline
\end{tabular}

Table 12. Projected Renewable Energy Generation: High Wind Case, 2007-2015 (GWh)

\begin{tabular}{|l|c|c|c|c|c|c|c|c|c|}
\hline & $\mathbf{2 0 0 7}$ & $\mathbf{2 0 0 8}$ & $\mathbf{2 0 0 9}$ & $\mathbf{2 0 1 0}$ & $\mathbf{2 0 1 1}$ & $\mathbf{2 0 1 2}$ & $\mathbf{2 0 1 3}$ & $\mathbf{2 0 1 4}$ & $\mathbf{2 0 1 5}$ \\
\hline Midwest & 12,369 & 21,733 & 25,140 & 29,070 & 34,741 & 41,034 & 47,783 & 54,544 & 62,034 \\
\hline New England & 817 & 992 & 1,261 & 1,577 & 1,959 & 2,388 & 2,836 & 3,311 & 4,133 \\
\hline New York & 1,452 & 2,513 & 2,910 & 3,367 & 3,852 & 4,388 & 4,785 & 5,184 & 5,792 \\
\hline Mid Atlantic & 3,667 & 5,097 & 6,303 & 7,748 & 9,470 & 11,433 & 13,540 & 15,817 & 18,430 \\
\hline Heartland & 3,445 & 4,983 & 5,754 & 6,643 & 8,675 & 10,932 & 15,085 & 19,237 & 24,506 \\
\hline Southeast & 2,222 & 2,915 & 3,389 & 3,943 & 4,591 & 5,375 & 6,363 & 7,449 & 8,953 \\
\hline Florida & 486 & 542 & 604 & 674 & 726 & 781 & 838 & 900 & 965 \\
\hline California & 4,698 & 5,344 & 11,514 & 18,238 & 24,245 & 31,296 & 36,117 & 42,233 & 47,043 \\
\hline West & 14,624 & 17,598 & 27,151 & 36,871 & 47,245 & 58,373 & 68,480 & 78,746 & 88,108 \\
\hline Texas & 13,587 & 21,923 & 24,502 & 27,476 & 31,713 & 36,417 & 42,059 & 47,704 & 52,428 \\
\hline Alaska & 79 & 88 & 96 & 105 & 115 & 126 & 138 & 150 & 164 \\
\hline Hawaii & 311 & 313 & 423 & 547 & 695 & 859 & 1,032 & 1,206 & 1,381 \\
\hline \hline Total & 57,759 & 84,039 & 109,047 & 136,260 & 168,028 & 203,401 & 239,056 & 276,480 & 313,937 \\
\hline
\end{tabular}




\section{Demand-Side Analysis}

The two main demand sources are voluntary purchases of renewable energy and state RPS policies. Consumers - individuals, corporations, and institutions - usually make voluntary purchases of green power through optional utility programs or through renewable energy certificates (RECs), separate from electricity. Load-serving entities also purchase renewable power or RECs to meet state RPS requirements. This analysis focuses only on the new renewable energy required to meet state RPS requirements, consistent with the supply-side focus on new renewables. It is assumed that at least until 2015, all eligible renewable energy generation will be used to supply either compliance (RPS) or voluntary renewable energy markets.

Note that a few utilities have invested in owning or purchasing renewable energy or RECs, because they are least-cost resources in their area. These cases are ignored in this analysis, despite the fact that they are made regardless of RPS requirements or voluntary demand.

\section{Voluntary Markets}

Estimates of demand for renewable energy by voluntary purchasers are based on data reported by NREL for utility programs, competitively marketed green power products, and nationally sourced REC products offered by marketers (Bird et al. 2008). Table 13 presents estimates of voluntary market demand for 2004-2007. Demand is reported by region by assigning utility programs to the region in which the utility operates; this should be reasonably accurate because most utilities typically supply their programs with local sources of renewable energy. In addition, RECs sold by marketers are assigned to a particular region if the specific marketer focuses on serving customers and procuring supplies from a particular region. All other REC market transactions are categorized as "national," because many marketers procure RECs from renewable energy sources located anywhere in the country and sell them primarily to businesses that have facilities scattered across the country.

The projections for demand for nationally sourced RECs and regional voluntary demand are based on linear growth trends from 2004 through 2007. A linear regression was used to estimate future voluntary market demand in each region. The forecast for voluntary demand in Florida was modified due to the cancellation of the Florida Power and Light green power program in mid-2008, which represented more than $90 \%$ of voluntary demand in Florida in 2004-2007. The remaining demand in Florida is assumed to increase $10 \%$ annually. Table 14 presents regional projections of voluntary market demand in gigawatt hours by region from 2008-2015. The method used here is conservative compared to applying historic voluntary market annual growth rates going forward. The overall voluntary renewable energy market grew at a $48 \%$ annual average rate from 2003-2007.

The financial crisis is likely to impact voluntary market demand, particularly in the near term. Because the impact is difficult to predict, it is not specifically addressed; but, as noted, conservative assumptions about future growth are used. Also, it is important to 
note that voluntary market demand is price-sensitive and could be affected by growing RPS demand and price increases resulting from regional shortages. These issues are not specifically addressed in this analysis.

Table 13. Voluntary Demand by Region, 2004-2007 (GWh)

\begin{tabular}{|l|c|c|c|c|}
\hline & $\mathbf{2 0 0 4}$ & $\mathbf{2 0 0 5}$ & $\mathbf{2 0 0 6}$ & $\mathbf{2 0 0 7}$ \\
\hline Midwest & 159 & 283 & 439 & 499 \\
\hline New England & 214 & 380 & 365 & 470 \\
\hline New York & 132 & 202 & 200 & 296 \\
\hline Mid Atlantic & 342 & 759 & 1,461 & 1,885 \\
\hline Heartland & 57 & 69 & 144 & 182 \\
\hline Southeast & 63 & 85 & 106 & 130 \\
\hline Florida & 59 & 114 & 153 & 189 \\
\hline California & 305 & 325 & 424 & 560 \\
\hline West & 1,128 & 1,221 & 1,591 & 2,249 \\
\hline Texas & 434 & 484 & 665 & 1,983 \\
\hline Alaska & 0 & 0 & 0 & 0 \\
\hline Hawaii & 0 & 0 & 0 & 0 \\
\hline National & 3,321 & 4,564 & 6,364 & 9,576 \\
\hline \hline Total & 6,213 & 8,487 & 11,912 & 18,019 \\
\hline
\end{tabular}

Table 14. Projected Voluntary Demand by Region, 2008-2015 (GWh)

\begin{tabular}{|l|c|c|c|c|c|c|c|c|}
\hline & $\mathbf{2 0 0 8}$ & $\mathbf{2 0 0 9}$ & $\mathbf{2 0 1 0}$ & $\mathbf{2 0 1 1}$ & $\mathbf{2 0 1 2}$ & $\mathbf{2 0 1 3}$ & $\mathbf{2 0 1 4}$ & $\mathbf{2 0 1 5}$ \\
\hline Midwest & 599 & 709 & 818 & 928 & 1,038 & 1,147 & 1,257 & 1,367 \\
\hline New England & 564 & 643 & 722 & 800 & 879 & 958 & 1,037 & 1,116 \\
\hline New York & 355 & 409 & 463 & 517 & 571 & 625 & 679 & 733 \\
\hline Mid Atlantic & 2,261 & 2,758 & 3,254 & 3,751 & 4,248 & 4,744 & 5,241 & 5,737 \\
\hline Heartland & 219 & 263 & 306 & 350 & 394 & 438 & 481 & 525 \\
\hline Southeast & 156 & 179 & 202 & 225 & 248 & 271 & 294 & 317 \\
\hline Florida & 227 & 40 & 45 & 49 & 54 & 59 & 65 & 72 \\
\hline California & 672 & 769 & 866 & 963 & 1,060 & 1,157 & 1,253 & 1,350 \\
\hline West & 2,699 & 3,116 & 3,533 & 3,950 & 4,367 & 4,783 & 5,200 & 5,617 \\
\hline Texas & 2,380 & 2,919 & 3,458 & 3,997 & 4,536 & 5,075 & 5,614 & 6,153 \\
\hline Alaska & 0 & 0 & 0 & 0 & 0 & 0 & 0 & 0 \\
\hline Hawaii & 0 & 0 & 0 & 0 & 0 & 0 & 0 & 0 \\
\hline National & 12,928 & 15,350 & 17,773 & 20,195 & 22,618 & 25,040 & 27,463 & 29,885 \\
\hline \hline Total & 23,059 & 27,154 & 31,439 & 35,725 & 40,011 & 44,298 & 48,585 & 52,873 \\
\hline
\end{tabular}




\section{Compliance (RPS) Markets}

To determine demand from RPS policies, the analysis used estimates of the new renewable energy necessary to comply with each state policy through 2015 . These RPS demand estimates were originally developed by the Union of Concerned Scientists (UCS) and updated and modified by Lawrence Berkeley National Laboratory (Barbose 2008, Wiser and Barbose 2008). ${ }^{20}$ While some states allow existing renewables to meet the RPS requirement, the estimates used here focus on RPS demand for new renewable energy supplies that would be needed to fully comply with current RPS policies. Also, the estimates here do not account for utilities that may pay alternative compliance payments (ACPs) to achieve compliance with RPS policies, rather than procuring renewable energy.

Table 15 shows the new renewable energy generation $(\mathrm{GWh})$ required annually to meet existing state RPS policies between 2004 and 2007 in each region. Table 16 presents projections of the new renewable energy generation needed to meet RPS policies in each region through 2015, assuming full compliance with each state policy. State RPS demand was assigned to a region based on the assumptions described earlier; in two instances (Illinois and Montana), state demand was split across regions.

Combining state RPS requirements by region assumes that a state can look beyond its borders for eligible resources. Regional trading is, in fact, allowed under many state RPS statutes, as discussed earlier. The regional trading space for RPS compliance is most often a function of the transmission network and wholesale power markets, which are the basis for the regions used in this analysis.

\footnotetext{
${ }^{20}$ Note that the RPS compliance estimates presented here are considerably different than those reported in Swezey et al. (2007) because of modifications to the assumptions used in calculating the new renewables requirements in some states (most notably California), as well as the addition of new RPS policies and the expansion of a number of RPS targets.
} 
Table 15. Compliance Requirements by Region for "New" Renewable Energy, 2004-2007 (GWh)

\begin{tabular}{|l|c|c|c|c|}
\hline & $\mathbf{2 0 0 4}$ & $\mathbf{2 0 0 5}$ & $\mathbf{2 0 0 6}$ & $\mathbf{2 0 0 7}$ \\
\hline Midwest & 2,641 & 2,958 & 4,682 & 4,097 \\
\hline New England & 721 & 984 & 1,199 & 1,531 \\
\hline New York & 0 & 0 & 1,147 & 2,377 \\
\hline Mid Atlantic & 8 & 13 & 30 & 153 \\
\hline Heartland & 0 & 0 & 0 & 0 \\
\hline Southeast & 0 & 0 & 0 & 0 \\
\hline Florida & 0 & 0 & 0 & 0 \\
\hline California & 0 & 0 & 0 & 0 \\
\hline West & 486 & 468 & 1,306 & 2,654 \\
\hline Texas & 1,578 & 3,353 & 3,353 & 5,523 \\
\hline Alaska & 0 & 0 & 0 & 0 \\
\hline Hawaii & 0 & 54 & 0 & 0 \\
\hline \hline Annual Total & 5,434 & 7,830 & 11,717 & 16,335 \\
\hline
\end{tabular}

Table 16. Compliance Requirements by Region for "New" Renewable Energy, 2008-2015 (GWh)

\begin{tabular}{|l|l|l|l|l|l|l|l|l|}
\hline & $\mathbf{2 0 0 8}$ & $\mathbf{2 0 0 9}$ & $\mathbf{2 0 1 0}$ & $\mathbf{2 0 1 1}$ & $\mathbf{2 0 1 2}$ & $\mathbf{2 0 1 3}$ & $\mathbf{2 0 1 4}$ & $\mathbf{2 0 1 5}$ \\
\hline Midwest & 4,556 & 5,750 & 10,745 & 11,655 & 17,728 & 18,717 & 20,814 & 32,227 \\
\hline New England & 2,334 & 3,186 & 4,321 & 5,588 & 6,900 & 8,204 & 9,549 & 10,570 \\
\hline New York & 3,625 & 4,869 & 6,138 & 7,449 & 8,733 & 10,055 & 10,055 & 10,055 \\
\hline Mid Atlantic & 1,112 & 2,520 & 6,168 & 8,875 & 11,642 & 14,454 & 18,084 & 22,140 \\
\hline Heartland & 0 & 0 & 0 & 0 & 0 & 0 & 0 & 0 \\
\hline Southeast & 0 & 0 & 7 & 988 & 2,300 & 2,479 & 4,105 & 5,928 \\
\hline Florida & 0 & 0 & 0 & 0 & 0 & 0 & 0 & 0 \\
\hline California & 1,583 & 4,083 & 17,815 & 21,093 & 22,151 & 22,885 & 23,628 & 24,972 \\
\hline West & 3,758 & 4,745 & 5,581 & 9,686 & 11,532 & 13,071 & 13,783 & 22,903 \\
\hline Texas & 5,523 & 9,436 & 9,436 & 13,349 & 13,349 & 17,262 & 17,262 & 19,724 \\
\hline Alaska & 0 & 0 & 0 & 0 & 0 & 0 & 0 & 0 \\
\hline Hawaii & 0 & 0 & 54 & 54 & 54 & 54 & 54 & 133 \\
\hline Annual Total & 22,490 & 34,588 & 60,264 & 78,736 & 94,388 & 107,181 & 117,334 & 148,653 \\
\hline
\end{tabular}




\section{Sum of Voluntary and Compliance Market Demand}

The projections in this analysis show that demand for new renewable energy will reach about 210 TWh annually by 2015 (this estimate does not include nonbinding state renewable energy targets). Figure 3 shows the sum of the state RPS demand and the voluntary market demand through 2015 . It is important to note that the elasticity of voluntary demand is not taken into account. Unlike compliance demand, which feels little effect from price fluctuations, the level of voluntary demand can change inversely to changes in REC prices. In other words, extreme increases in REC prices due to overall scarcity may cause voluntary demand to be less than projected in Figure 3.

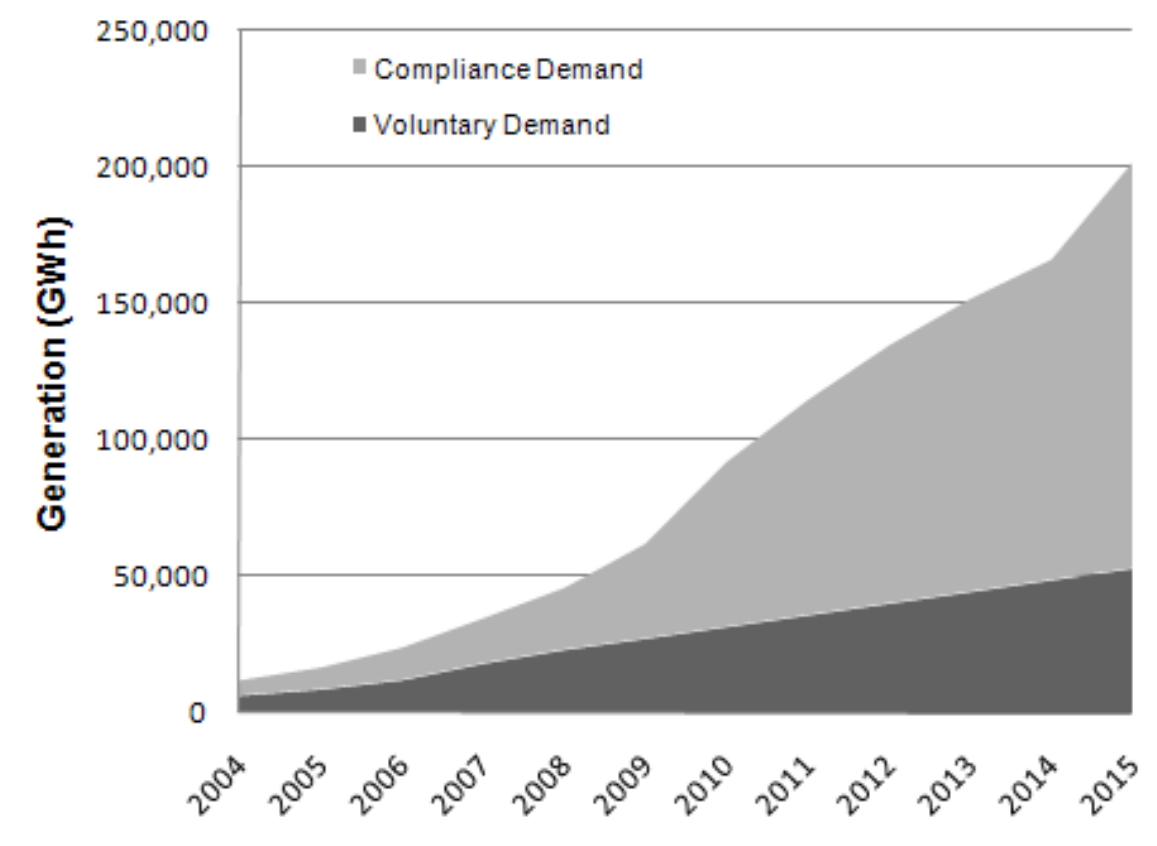

Figure 3. Historic and projected demand for "new" renewable energy, 2004-2015 


\section{The Supply and Demand Balance}

Figure 4 compares our demand estimate for new renewable electricity from voluntary and compliance (RPS) markets with our two renewable electricity supply scenarios in 2010 and 2015. The business as usual (BAU) case reflects continued development of renewables at current rates. The high wind case represents an overall accelerated growth scenario for wind, or high renewable-generation case. Note that the "high wind case" is not a high case in all regions and years, because the method used in the high wind case to apportion wind across regions differs from that used in the BAU case (see earlier discussion under Supply Estimates section).

Tables 17 and 18 show current and projected regional new renewable energy generation net of RPS demand and voluntary market demand within the region for 2004 through 2015. Voluntary market demand for RECs sourced from facilities nationally is then subtracted from the sum of the regional balances.
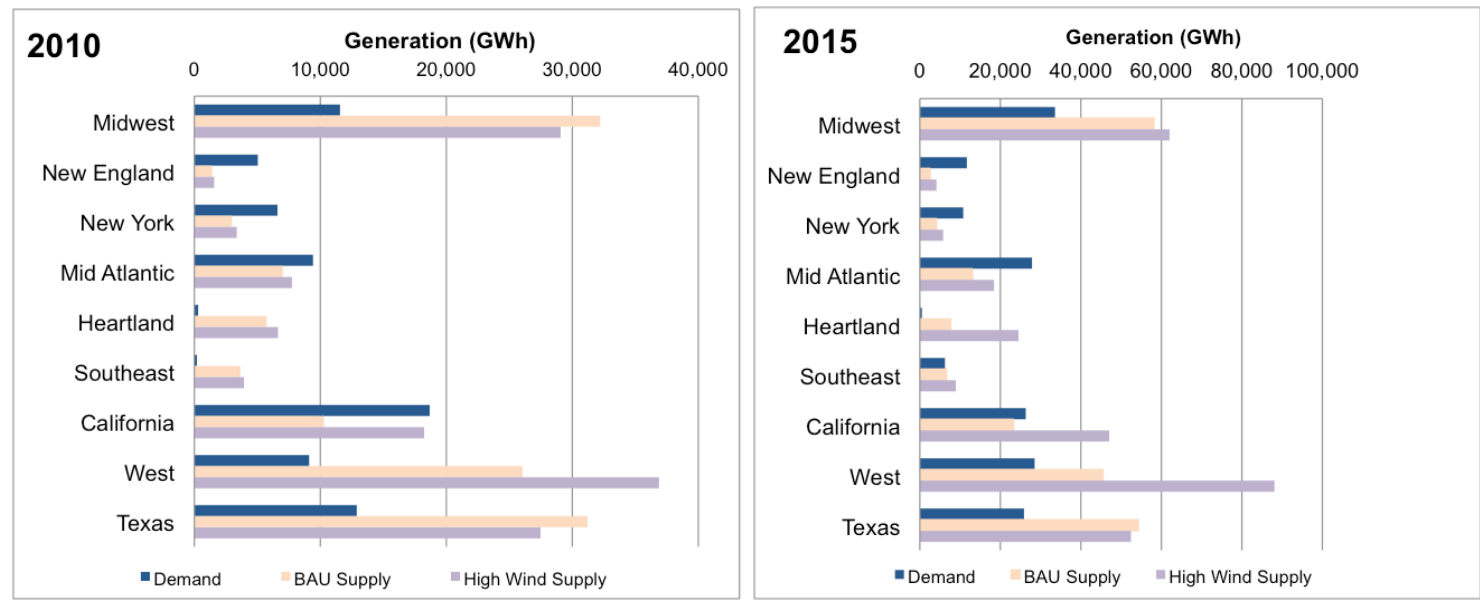

Figure 4. Regional demand and supply under the two cases in 2010 and 2015 (GWh)

Under both the BAU and high wind scenarios, renewable energy deficits are projected for New England, New York, and the Mid-Atlantic areas, ${ }^{21}$ with notable surpluses projected for the Midwest, Heartland, Texas, and the West. It is important to note that this analysis does not assume trading between the regions specified in the analysis; although, in some cases, such trading may be feasible and could address potential shortages, to the extent that it is not limited by transmission access or state RPS REC trading rules.

In New England, deficits are shown historically (years prior to 2008) and increase in size through 2015 under both scenarios. Projected shortages are about 3,500 GWh in 2010 under both scenarios, and range from 7,500 GWh to more than 9,000 GWh in 2015. It is

\footnotetext{
${ }^{21}$ It is important to note that this analysis assumes that offshore wind does not come online during the period of the analysis. There are currently efforts to develop offshore wind in the New England and MidAtlantic regions. If those efforts are successful in the near term, the shortages projected here would likely not materialize.
} 
important to note that the study does not consider the development of offshore wind in the region over the study period. If offshore wind resources were developed, the shortages projected here for the Eastern regions most likely would not occur.

Similarly, in New York, deficits appear in 2006 under both scenarios and extend through 2015. Shortages are projected to grow in size through 2013 and then decline modestly. Projected shortages exceed 3,000 GWh in 2010 under both scenarios and range from about 5,000 GWh to nearly 7,000 GWh in 2015 .

In the Mid-Atlantic, deficits first appear in 2010 under both scenarios and increase in magnitude through 2015. Projected shortages are about 2,000 GWh in 2010 and range from about 9,000 GWh to 15,000 GWh in 2015.

Relatively large amounts of excess renewable energy generation - about 10,000 GWh to 50,000 GWh annually - are projected for the Midwest, the West, and Texas under both scenarios. In the Heartland region, excess generation is projected to be about 5,000 GWh in 2010 and to grow over time. There is a wide range in the estimates of excess generation in the Heartland in 2015 - ranging from 7,000 GWh to 24,000 GWh under the $\mathrm{BAU}$ and high wind scenarios, respectively, as the high wind case assumes a significant amount of relatively cost-effective wind generation is developed in the region. More modest surpluses are projected for the Southeast, Florida, Alaska, and Hawaii.

In California, a shortfall of about $8,000 \mathrm{GWh}$ is projected starting in 2010 under the BAU scenario but diminishes in later years. Under the high wind energy scenario, California is projected to have excess generation except for a small shortfall (400 GWh) in 2010. Shortages in California, in particular, could potentially be offset by surplus supply projected elsewhere in the West, to the extent that excess generation can meet California's RPS deliverability requirements. ${ }^{22}$ Such interregional transfers were not considered in the analysis.

Appendix B provides graphs for each region and more detailed information on the regional renewable energy supply and demand balances.

\section{$\underline{\text { Addressing Barriers to Alleviate Shortfalls }}$}

In some regions where current and future shortfalls are shown in the analysis, barriers to development of renewables have played a role. For example, barriers to siting and permitting renewable energy projects, including offshore wind, have limited the development of new renewables in some regions. Furthermore, the load-serving entities subject to RPS requirements particularly in restructured electricity markets - such as in New England and the Mid-Atlantic - have been hesitant to enter into long-term contracts for renewable energy supplies, limiting the ability of renewable energy projects in the

\footnotetext{
${ }^{22}$ Excess supplies in the West could be used to meet projected shortfalls in California to the extent that they could meet California's current RPS deliverability requirements. The expanded use of RECs in California has been considered; but, as of the time of this writing, had not been approved.
} 
region to obtain financing. ${ }^{23}$ However, these issues may be addressed in the future, because a number of states have recently adopted policy changes to alleviate these problems. For example, Massachusetts requires the default service providers to sign 15year contracts (DSIRE 2009). If these policies succeed and the barriers are removed, the rate of renewable energy development will likely accelerate above historical rates in these regions.

\section{Market Mechanisms for Alleviating Shortfalls}

In the absence of barriers, market economics are expected to gradually encourage the addition of new capacity and accelerated development in regions with projected shortfalls. As shortages push prices higher in New England, the Mid-Atlantic, and California, renewable resources in these regions that are currently marginal will become economically viable. At the same time, higher prices may put downward pressure on voluntary demand in these same regions.

Regional shortfalls could be alleviated by tapping into excess generation in adjacent regions. For example, shortfalls in generation within California could be addressed through excess supplies estimated for the West, if generation can comply with the California RPS deliverability requirements. And while not addressed in this analysis, imports from Canada could contribute supply, if excess generation is available.

\section{$\underline{\text { Transmission Limits and Interregional Trading }}$}

The ability of interregional deliveries to address shortage situations will be limited by the availability of transmission and the cost of delivering electricity. In some cases, moving sufficient quantities of electricity interregionally requires using bulk transmission lines, which currently do not exist. For example, while excess generation in the Midwest Reliability Organization (MRO) in the out-years could be used to meet projected shortfalls in the Mid-Atlantic (RFC and NY), transmission does not exist to facilitate interregional deliverability. Although the technical feasibility of interregional transmission is under study in both the Western and Eastern Interconnections, the greatest obstacles are institutional rather than technical. Critical issues such as cost allocation for interstate transmission are beyond the jurisdiction of any individual state, while federal authority on route approval and site permitting is generally limited.

While an interregional transmission strategy would increase the use of the least-cost wind resources - and consequently reduce wholesale power prices - the overall savings in production costs would have to be balanced against the additional transmission cost and the additional costs (if any) of maintaining grid reliability. As found in the $20 \%$ wind study, achieving this objective could create an incremental cost of $2 \%$ more than business

\footnotetext{
${ }^{23}$ Many of these states underwent electric-generation deregulation - or electric-sector restructuring - and for both the competitive suppliers and the default investor-owned utilities, it is unclear how much demand they will have more than a few years out. Under these uncertain circumstances, it would not make much sense to sign long-term contracts of 10 or 20 years that are needed to help finance and build new renewable projects in the area.
} 
as usual, including the cost of new transmission and natural gas combustion turbines to maintain adequate reserves (DOE 2008).

What is clear, however, is that marginal resources will replace those that could provide more power at a lower cost if there is insufficient infrastructure to bring the least-cost resources to market. Most of the lowest-cost inland wind resources, for example, are in the Great Plains where growth has been robust but intraregional demand is relatively small. Without bulk transmission across regional seams, much of the nation's least-cost wind resources may remain untapped.

For example, a production cost analysis conducted by a consortium of RTOs in the Eastern Interconnection suggested that wholesale power prices in PJM, New York, and New England would be 34\% to 41\% lower by 2027 if a high-penetration wind scenario were achieved with expanded interregional transmission. This is opposed to achieving the same wind target using local transmission upgrades on the existing system as currently constrained between regions (JCSP 2008). Accompanying the price reduction was a change where wind capacity growth would occur: less in PJM and SERC (where the average wind capacity factor was estimated at around 35\%) and more in MRO and SPP (with an estimated wind capacity factor of $45 \%$ ).

\section{Expanded Regional REC Trading as Solution}

A more policy-driven approach to addressing potential shortfalls is expanded REC trading across regional seams. ${ }^{24}$ At least in the near term, a surplus in one region would most likely be large enough to satisfy internal shortages in neighboring regions. For example, if states adopted broader geographic eligibility regions - which would relax deliverability requirements - excess supplies in the upper Midwest could be used to achieve compliance in New England and the Mid-Atlantic, and perhaps take advantage of lower-cost resources. However, such trading may come at the expense of interest on the part of states in driving more local economic development, which is often a goal of statelevel RPS requirements (see, for example, Holt 2008).

\footnotetext{
${ }^{24}$ The Environmental Tracking Network of North America (ETNNA) is convening a national dialogue, the goal of which is to address the technical issues associated with interregional REC trading. If successful, ETNNA's efforts will create a foundation where it will be possible to trade RECs among regions; the actual practice will likely depend on the state rules for eligible renewable resources for their RPS (not addressed by ETNNA).
} 
Table 17. Business as Usual Case: Renewable Energy Generation Net of Regional RPS Demand and Regional Voluntary

\begin{tabular}{|c|c|c|c|c|c|c|c|c|c|c|c|c|}
\hline \multicolumn{13}{|c|}{ and } \\
\hline & 2004 & 2005 & 2006 & 2007 & 2008 & 2009 & 2010 & 2011 & 2012 & 2013 & 2014 & 2015 \\
\hline MRO & 1,479 & 2,345 & 1,732 & 7,774 & 16,578 & 20,497 & 20,649 & 24,793 & 23,783 & 27,868 & 30,857 & 24,546 \\
\hline NPCC & -450 & -735 & -911 & $-1,184$ & $-1,905$ & $-2,642$ & $-3,637$ & $-4,789$ & $-5,966$ & $-7,120$ & $-8,288$ & $-9,117$ \\
\hline$\overline{N Y}$ & 190 & 486 & -213 & $-1,221$ & $-1,467$ & $-2,528$ & $-3,608$ & $-4,748$ & $-5,859$ & $-7,007$ & $-6,830$ & $-6,650$ \\
\hline RFC & 1,981 & 1,872 & 1,518 & 1,629 & 1,723 & 727 & $-2,389$ & $-4,659$ & $-6,888$ & $-9,041$ & $-11,842$ & $-14,790$ \\
\hline SPP & 776 & 2,249 & 2,246 & 3,263 & 4,764 & 5,101 & 5,438 & 5,775 & 6,112 & 6,449 & 6,785 & 7,122 \\
\hline SERC & 1,459 & 1,503 & 1,797 & 2,093 & 2,759 & 3,071 & 3,435 & 2,856 & 2,059 & 2,408 & 1,407 & 429 \\
\hline FRCC & 332 & 214 & 255 & 297 & 314 & 564 & 630 & 677 & 727 & 779 & 834 & 893 \\
\hline \begin{tabular}{|l|} 
Eastern \\
Interconnect
\end{tabular} & 5,376 & 7,933 & 6,425 & 12,651 & 22,766 & 24,789 & 20,518 & 19,905 & 13,966 & 14,335 & 12,924 & 2,432 \\
\hline$\overline{C A}$ & 2,407 & 2,710 & 3,624 & 4,138 & 3,088 & 2,989 & $-8,398$ & $-9,208$ & $-7,456$ & $-6,348$ & $-4,243$ & $-3,053$ \\
\hline WECC & 3,052 & 5,201 & 5,982 & 9,721 & 11,141 & 14,445 & 16,935 & 16,411 & 17,911 & 19,744 & 22,564 & 16,960 \\
\hline \begin{tabular}{|l|} 
Western \\
Interconnect
\end{tabular} & 5,459 & 7,911 & 9,606 & 13,859 & 14,229 & 17,434 & 8,537 & 7,203 & 10,455 & 13,396 & 18,322 & 13,907 \\
\hline ERCOT & 1,687 & 2,151 & 4,780 & 6,081 & 14,021 & 14,201 & 18,306 & 18,463 & 22,536 & 22,697 & 26,774 & 28,393 \\
\hline ASCC & 38 & 46 & 73 & 79 & 88 & 95 & 102 & 110 & 118 & 127 & 137 & 147 \\
\hline HICC & 65 & 33 & 225 & 311 & 313 & 324 & 278 & 287 & 296 & 306 & 316 & 248 \\
\hline $\begin{array}{l}\text { Sum of } \\
\text { Regional } \\
\text { Balances }\end{array}$ & 12,589 & 18,074 & 21,110 & 32,981 & 51,417 & 56,843 & 47,741 & 45,968 & 47,371 & 50,861 & 58,473 & 45,127 \\
\hline $\begin{array}{l}\text { Voluntary } \\
\text { Demand for } \\
\text { Natl RECs }\end{array}$ & 3,321 & 4,564 & 6,364 & 9,576 & 12,928 & 15,350 & 17,773 & 20,195 & 22,618 & 25,040 & 27,463 & 29,885 \\
\hline $\begin{array}{l}\text { Net } \\
\text { Generation } \\
\text { Nationally }\end{array}$ & 99,268 & $\overline{13,510}$ & $\overline{14,745}$ & 23,405 & 38,489 & 41,493 & 29,968 & 25,773 & 24,753 & 25,821 & 31,010 & 15,242 \\
\hline
\end{tabular}


Table 18. High Wind Case: Renewable Energy Generation Net of Regional RPS Demand and Regional Voluntary

\begin{tabular}{|c|c|c|c|c|c|c|c|c|c|c|c|c|}
\hline \multicolumn{13}{|c|}{ Renewables Demand (GWh) } \\
\hline & 2004 & 2005 & 2006 & 2007 & 2008 & 2009 & 2010 & 2011 & 2012 & 2013 & 2014 & 2015 \\
\hline MRO & 1,479 & 2,345 & 1,732 & 7,774 & 16,578 & 18,681 & 17,507 & 22,159 & 22,268 & 27,919 & 32,473 & 28,440 \\
\hline NPCC & -450 & -735 & -911 & $-1,184$ & $-1,905$ & $-2,567$ & $-3,465$ & $-4,429$ & $\begin{array}{l}-5,391 \\
\end{array}$ & $-6,326$ & $-7,275$ & $-7,553$ \\
\hline NY & 190 & 486 & -213 & $-1,221$ & $-1,467$ & $-2,368$ & $-3,234$ & $-4,114$ & $-4,916$ & $-5,896$ & $-5,551$ & $-4,996$ \\
\hline RFC & 1,981 & 1,872 & 1,518 & 1,629 & 1,723 & 1,025 & $-1,674$ & $-3,156$ & $-4,457$ & $-5,658$ & $-7,508$ & $-9,447$ \\
\hline SPP & 776 & 2,249 & 2,246 & 3,263 & 4,764 & 5,491 & 6,336 & 8,325 & 10,538 & 14,647 & 18,755 & 23,981 \\
\hline \begin{tabular}{|l} 
SERC \\
\end{tabular} & 1,459 & 1,503 & 1,797 & 2,093 & 2,759 & 3,210 & 3,734 & 3,378 & 2,828 & 3,614 & 3,050 & 2,708 \\
\hline FRCC & -59 & 214 & 255 & 297 & 314 & 564 & 630 & 677 & 727 & 779 & 834 & 893 \\
\hline \begin{tabular}{|l|} 
Eastern \\
Interconnect
\end{tabular} & 5,376 & 7,933 & 6,425 & 10,164 & 18,778 & 19,321 & 14,274 & 15,291 & 11,835 & 15,208 & 16,800 & 10,821 \\
\hline$\overline{C A}$ & 2,407 & 2,710 & 3,624 & 4,138 & 3,088 & 6,662 & -442 & 2,190 & 8,086 & 12,076 & 17,352 & 20,720 \\
\hline WECC & 3,052 & 5,201 & 4,676 & 9,721 & 11,141 & 19,290 & 27,758 & 33,610 & 42,474 & 50,625 & 59,763 & 59,588 \\
\hline \begin{tabular}{|l|} 
Western \\
Interconnect
\end{tabular} & 5,459 & 7,911 & 8,300 & 13,859 & 14,229 & 25,952 & 27,316 & 35,800 & 50,560 & 62,700 & 77,114 & 80,308 \\
\hline ERCOT & 1,687 & 2,151 & 4,780 & 6,081 & $\begin{array}{c}14,02 \\
1 \\
\end{array}$ & 12,148 & 14,582 & 14,368 & 18,532 & 19,722 & 24,828 & 26,552 \\
\hline ASCC & 3 & 46 & 73 & 79 & 88 & 96 & 105 & 115 & 126 & 138 & 150 & 164 \\
\hline HICC & 65 & 33 & 225 & 311 & 313 & 423 & 492 & 640 & 805 & 978 & 1,152 & 1,248 \\
\hline $\begin{array}{l}\text { Sum of } \\
\text { Regional } \\
\text { Balances }\end{array}$ & 12,589 & 18,074 & 19,804 & 32,981 & 51,417 & 62,655 & 62,330 & 73,762 & 91,621 & 112,617 & 138,024 & 142,298 \\
\hline $\begin{array}{l}\text { Voluntary } \\
\text { Demand for } \\
\text { Natl RECs }\end{array}$ & 3,321 & 4,564 & 6,364 & 9,576 & 12,928 & 15,350 & 17,773 & 20,195 & 22,618 & 25,040 & 27,463 & 29,885 \\
\hline $\begin{array}{l}\text { Net } \\
\text { Generation } \\
\text { Nationally }\end{array}$ & 9,268 & $\overline{~ 13,510}$ & 13,439 & 23,405 & 38,489 & 47,305 & 444,558 & $\overline{53,567}$ & 699,003 & 87,577 & $\overline{1110,561}$ & $\overline{112,412}$ \\
\hline
\end{tabular}




\section{Key Uncertainties}

The projections in this report are based on historical trends and current policies; they show where a region is likely to end up in the absence of any major policy change, market shock, or change in the rate of renewable energy development. However, a number of factors can alter the future balance between renewable electric supply and demand.

\section{Adoption of Additional State RPS Policies, Federal RPS, or Climate Policies} As of early 2009, 28 states and the District of Columbia have RPS policies. If additional states pass RPS laws or increase existing renewable energy targets - or if a federal RPS is enacted - compliance demand (and supplies) could increase significantly. However, additional policies would not be expected to have a measurable impact until several years after they are adopted. Similarly, the adoption of any federal policy to address climate change may impact demand for and deployment of renewables. Assuming such policies address interconnection, transmission, long-term financing support, and include enforcement provisions, the market would likely respond to this higher level of demand by developing new supply.

\section{Federal Renewable Energy Tax Credits}

Renewable energy development relies on a number of federal tax incentives, including the production tax credit (PTC) for wind and other renewables and the solar investment tax credit (ITC). Uncertainty surrounding reauthorization of these incentives has historically delayed renewable energy project development. The solar ITC was recently extended through 2016 and made available to utilities - this provides significantly greater certainty to the industry and will likely accelerate the rate of future development.

In addition, the American Recovery and Reinvestment Act (ARRA), which was signed into law by President Obama in February 17, 2009, includes an extension of the PTC through 2012 for wind, and 2013 for other renewables. It also includes a number of other tax provisions aimed at alleviating the impacts of the financial crisis (discussed in more detail below) such as temporary cash grants in lieu of tax credits for projects placed in service in 2009 or 2010, a credit for building renewable energy manufacturing facilities, and an option to use the ITC in lieu of the PTC. While these incentives were not specifically considered in this analysis, they could lead to accelerated renewable energy development, increased manufacturing, and supply levels above those assumed in this analysis, depending on how the financial crisis plays out.

\section{Financial Crisis}

As of March 2009, the global financial crisis is still unfolding and, therefore, it is difficult to determine the potential impacts on renewable energy project development during the period of the study. In late 2008 and early 2009, the national financial crisis limited the ability for most entities to take advantage of renewable energy tax incentives because of a lack of tax equity, and project developers were unable to turn to debt financing because the credit market appeared to be frozen. Provisions in the ARRA are designed to alleviate these concerns; but, because they were just recently adopted, their effectiveness is still 
uncertain. In addition, it is still unclear the effectiveness of efforts to stabilize the banking industry and increase access to debt.

While the effects of the financial crisis are still unclear at this time, it is possible that a lack of access to project financing in the short term could delay some renewable energy project development and shift it to later years. The pace of development in coming years will depend on the ability of the federal government and the financial industry to address the financial crisis and increase the availability of debt for project financing. Because of these significant uncertainties, we have not attempted to account for the potential impacts of the crisis in this analysis.

\section{RPS Compliance}

It is possible that some states will not achieve full compliance with their RPS requirements using renewable energy generation. If utilities or load-serving entities subject to the RPS pay an alternative compliance payment (ACP) instead of using renewable energy generation to meet RPS requirements, then the demand estimates here will be overstated. Some of the potential reasons that utilities might pay ACPs rather than procure renewable generation include:

- barriers to siting and permitting,

- inadequate transmission from areas with good renewable resources to areas of demand,

- lack of state provisions to support long-term financing of new renewable projects, financing challenges described above, and

- RPS cost caps set too low to provide incentives for new renewable project development (see, for example, Cory and Swezey 2007).

\section{Offshore Wind}

This analysis does not assume that offshore wind comes online during the period of the analysis. There are efforts underway to try to develop offshore wind along the coasts of New England and the Mid-Atlantic (and elsewhere). If those efforts are successful in the near term, the shortfalls projected in this analysis for those regions would likely disappear.

\section{Transmission Access}

The levels of wind energy development in the two scenarios presented here assume adequate access to transmission. Development has generally relied on the transmission capacity already available. If new transmission is not built to accommodate increased supply, the levels of wind energy development assumed here may not be achieved.

A number of initiatives are under way to address transmission issues. Texas is leading these efforts with its Competitive Renewable Energy Zone (CREZ) development. In the summer of 2008, the Public Utility Commission of Texas adopted a plan to build highvoltage transmission to the five areas of the state with the best potential for large-scale wind development (PUCT 2008). California, Colorado, Arizona, Nevada, New Mexico, and Utah are also conducting their own assessments of in-state renewable energy potential. 
In addition, the Western Governors' Association is conducting a regional initiative to identify renewable energy zones throughout the Western Interconnection (WGA 2008). The goal of this initiative is to identify high concentrations of low-cost renewable energy resources that could be moved regionally across a number of states via new high-voltage transmission lines.

The Midwest Independent System Operator (ISO) has begun its own phased study of regional wind development, initially examining scenarios to connect up to $15 \mathrm{GW}$ of wind power from the Dakotas, Minnesota, Iowa, Wisconsin, and Illinois (Midwest ISO 2009). In addition, NREL's National Wind Technology Center (NWTC) is assisting major grid operators throughout the Eastern Interconnection in developing outcomes for wind-penetration scenarios of up to $30 \% .{ }^{25}$

\section{Banking or Holding RECs}

If a significant number of utilities or electricity suppliers in supply-constrained areas choose to bank RECs for future RPS compliance, excess supplies may not be available. This may be the case if supplies are expected to remain constrained in the future. Furthermore, if generators choose to hold RECs in anticipation of future regulation, this would also reduce total supply in the short term. On the other hand, the availability of banking may make it possible for utilities to hold RECs to achieve compliance in future years, reducing shortfalls.

\section{Growth in Voluntary Markets}

Recent growth in voluntary market purchases has depended on an adequate supply of renewable electricity at a reasonable price. If REC shortages develop, it is likely that REC prices will increase. Higher prices would likely dampen voluntary demand. Because RPS demand is considerably less price-sensitive, it could outbid some existing voluntary demand as state noncompliance penalties and alternative compliance payment levels set the market price.

\footnotetext{
${ }^{25}$ The transmission entities include the Midwest Independent System Operator, PJM Interconnection, Southwest Power Pool, Tennessee Valley Authority (TVA), New York Independent System Operator, and ISO New England. All but TVA are regional transmission organizations.
} 


\section{Conclusions}

Given current policies and trends, this analysis found an overall national surplus of renewable energy generation to meet existing RPS policy targets and voluntary market demand. However, based on the assumptions in this analysis, some regional shortages are projected, while other regions are projected to have excess renewable energy supplies.

There are a number of key uncertainties in this analysis, including the impact of the global financial crisis, as well as changes in incentives or policies. ${ }^{26}$ The effects of the financial crisis are still unclear at this time, but it is possible that a lack of access to project financing in the short term could delay some project development and shift it to later years. While the pace of development in coming years will depend on the ability of the federal government and the financial industry to address the financial crisis and increase the availability of debt for project financing, the estimates presented here have not accounted for potential impacts of the crisis, because they are highly uncertain.

Based on the assumptions in this analysis, renewable energy deficits are projected for New England, New York, and the Mid-Atlantic areas, with notable surpluses in the Midwest, the Heartland, Texas, and the West. The BAU scenario, which is based on an extrapolation of recent development trends, found an internal shortfall for California starting in 2010; although, under the high wind energy scenario, California had excess supplies in every year except 2010. This analysis does not assume trading among the regions specified here; although, in some cases, such trading may be feasible to the extent that it is not limited by transmission access or state RPS REC trading rules. For example, projected shortages in California, which is treated as an independent region in the analysis, could possibly be offset by surplus supply projected elsewhere in the West.

Shortfalls could also be addressed through price signals that may accelerate development of renewable energy resources that are currently uneconomic. This is particularly true in areas that have fewer market barriers. In areas with market barriers, removing barriers to development, adding new transmission, and expanding regional trading could alleviate potential regional shortfalls. The role of federal government in addressing the financial crisis will also be critical, in terms of increasing the availability of debt, increasing investor confidence in the market as a whole, and making the renewable tax credits usable in the short term.

In regions with projected shortfalls, such as the Northeast, barriers to development have impeded siting, permitting, and project financing in recent years. States have begun to address these concerns, and the rate of renewable energy development will likely accelerate to the extent these policies are successful. Also, if offshore wind can be developed over the period of the analysis, this could also address potential shortages projected in the East.

\footnotetext{
${ }^{26}$ This analysis reflects existing policies, except those established very recently under the American Recovery and Reinvestment Act, signed into law by President Barack Obama in February 2009.
} 
Shortfalls could also be eliminated if interregional transfers were facilitated through upgrades to the transmission system. At least in the near term, a surplus in one region would most likely be large enough to satisfy internal shortages in neighboring regions. However, actually moving sufficient quantities interregionally requires bulk transmission lines that don't exist. Expanded transmission capacity would enable excess capacity from the Great Plains to meet expected shortfalls in New England and the Mid-Atlantic. While this approach has the benefit of reaching low-cost resources, transmission siting and cost allocation have their own cost and political challenges.

Expanding interregional trading of RECs would be a policy-driven solution. Similar to transmission solutions, this approach may come at the expense of achieving more local economic benefits of renewables development, which is often a goal of RPS policies. Reliability issues may also place an effective ceiling on the ability of a region to produce surplus RECs, if transmission upgrades fail to keep pace. 


\section{References}

American Wind Energy Association (AWEA). (2009). "Wind Energy Grows By Record 8,300 MW in 2008: Smart Policies, Stimulus Bill Needed To Maintain Momentum In 2009," American Wind Energy Association news release, January 27, 2009 http://www.awea.org/newsroom/releases/wind_energy_growth2008_27Jan09.html

Barbose, G. (2008). Electricity Markets and Policy Group, Lawrence Berkeley National Laboratory, e-mail dated June 3, 2008.

Bird, L.; Kreycik, C.; and Friedman, B. (2008). Green Power Marketing in the United States: A Status Report (Eleventh Edition), NREL/TP-6A2-44094. Golden, CO: National Renewable Energy Laboratory, October 2008. http://www.nrel.gov/docs/fy09osti/44094.pdf

Bricker and Eckler. (2008). Ohio Senate Bill 221: Alternative Energy Portfolio Standard http://www.bgsu.edu/offices/econdev/sb221chart.pdf

BTM Consult ApS. (2008). International Wind Energy Development, World Market Update 2007, Forecast 2008-2012, March 2008.

Cory, K.; and Swezey, B. (2007). "Renewable Portfolio Standards in the States: Balancing Goals and Rules," The Electricity Journal, 20 (4), p.21-32, May 2007.

Denholm, P. (2008). NREL senior energy analyst, e-mail dated July 10, 2008.

Department of Energy (DOE). (2008), “20\% Wind Energy by 2030: Increasing Wind Energy's Contribution to Renewable Energy Supply," U.S. Department of Energy (DOE), July 2008. http://www1.eere.energy.gov/windandhydro/pdfs/41869.pdf

Database of State Incentives for Renewables and Efficiency (DSIRE). (2009).

"Massachusetts Renewable Portfolio Standard," Database for State Incentives for Renewables and Efficiency, administered by the North Carolina Solar Center, accessed January 22, 2009, at

http://www.dsireusa.org/library/includes/map2.cfm?CurrentPageID=1\&State=MA\&RE= $\underline{1 \& E E=1}$

Energy Information Administration (EIA). (2008a). "Renewable Energy Consumption and Electricity Preliminary 2007 Statistics," Table 4, U.S. Electric Net Summer Capacity, 2003-2007 (Megawatts). Accessed at

http://www.eia.doe.gov/cneaf/alternate/page/renew energy consump/rea prereport.html

EIA. (2008b). Assumptions to the Annual Energy Outlook 2008. Table 73. Capacity

Factors for Renewable Energy Generating Technologies in Three Cases. Pg. 149

http://www.eia.doe.gov/oiaf/aeo/assumption/pdf/0554(2008).pdf 
Goldstein, R. (2008). U.S. Environmental Protection Agency (EPA), program manager, Landfill Methane Outreach Program, e-mail dated August 6, 2008.

Holt, E. (2008), Increasing Coordination and Uniformity Among State Renewable Portfolio Standards. Prepared for the Clean Energy States Alliance and the Northeast/Mid-Atlantic RPS Collaborative, December 2008. http://www.cleanenergystates.org/Publications/CESA HoltRPS_Policy_Report_Dec2008.pdf

Joint Coordinated System Planning Study (JCSP). (2008). "Conceptual Transmission Refinement," (workshop presentation, Carmel, Indiana), October 2, 2008 http://www.midwestiso.org/publish/Document/25f0a7 11c1022c619 7b1f0a48324a/Wind\%20Future.pdf?action=download\& property=Attachment

Midwest ISO. (2009). "Regional Generation Outlet Study Scope Document," June 18, 2008; Midwest Independent Transmission System Operator (ISO), "Regional Generation Outlet Study Technical Review Group Indicative Scenario Results," February 17, 2009.

Prometheus Institute and Solar Energy Industries Association (SEIA). (2007). U.S. Solar Industry Year in Review, http://www.seia.org/galleries/pdf/Year_in_Review_2007_sm.pdf

Public Utility Commission of Texas (PUCT). (2008). Commission Staff's Petition for Designation of Competitive Renewable Energy Zones (Docket Number 33672), Order, August 15, 2008.

Sherwood, L. (2008). E-mail containing installed PV capacity by state from Interstate Renewable Energy Council, July 8, 2008.

Slack, K. (2008). U.S. Geothermal Power Production and Development Update, Geothermal Energy Association, August 2008. http://www.geoenergy.org/publications/reports/Geothermal_Update_August 7 2008 FINAL.pdf

Swezey, B.; Aabakken, J.; and Bird, L. (2007). A Preliminary Examination of the Supply and Demand Balance for Renewable Electricity, NREL/TP-670-42266. Golden, CO: National Renewable Energy Laboratory, October 2007. http://www.eere.energy.gov/greenpower/pdfs/42266.pdf

Western Governors' Association. (2008). Western Renewable Energy Zones Committee Charter (draft), May 21, 2008. http://www.westgov.org/wga/initiatives/wrez/

Wiser, R.; Barbose, G. (2008). Renewables Portfolio Standards in the United States - A Status Report with Data Through 2007, Lawrence Berkeley National Laboratory, April 2008. http://eetd.lbl.gov/ea/EMP/reports/lbnl-154e-revised.pdf 
Wiser, R.; Bolinger, M. (2008) Annual Report on U.S. Wind Power Installation, Cost, and Performance Trends: 2007, Lawrence Berkeley National Laboratory, LBNL 275-E, May 2008. http://eetd.lbl.gov/ea/EMP/reports/lbnl-275e.pdf

Wiser, R.; Bolinger, M. (2007). Annual Report on U.S. Wind Power Installation, Cost, and Performance Trends: 2006, Lawrence Berkeley National Laboratory, May 2007. http://eetd.lbl.gov/ea/EMP/reports/ann-rpt-wind-06.pdf 


\section{Appendix A. Planned Geothermal and CSP Projects}

\section{Table A1. Geothermal Developing Projects by Phase}

\begin{tabular}{|c|c|c|c|c|c|c|c|c|c|c|}
\hline State & \multicolumn{2}{|c|}{ Unconfirmed } & \multicolumn{2}{|r|}{ Phase I } & \multicolumn{2}{|c|}{ Phase II } & \multicolumn{2}{|r|}{ Phase III } & \multicolumn{2}{|r|}{ Phase IV } \\
\hline & $\#$ & $\mathbf{M W}$ & $\#$ & MW & $\#$ & MW & $\#$ & MW & $\#$ & MW \\
\hline Alaska & 1 & Unspecified & 3 & $35-75$ & 1 & $18-25$ & & & & \\
\hline Arizona & 1 & Unspecified & 1 & $2-20$ & & & & & & \\
\hline California & 1 & 20 & 9 & $321.7-349.7$ & 5 & $316-327$ & 2 & $80-150$ & 4 & 189.9 \\
\hline Colorado & & & 1 & \begin{tabular}{|c|}
10 \\
\end{tabular} & & & & & & \\
\hline Florida & & & 1 & $0.2-1$ & & & & & & \\
\hline Hawaii & & & 1 & Unspecified & 1 & 8 & & & & \\
\hline Idaho & & & 4 & $125-200$ & 1 & 100 & 1 & 26 & & \\
\hline Nevada* & 3 & Unspecified & 21 & $392-612$ & 10 & $216-409$ & 6 & $250-528$ & 5 & $224.5-352.5$ \\
\hline New Mexico & & & & & & & 1 & 10 & & \\
\hline Oregon & & & 7 & 112.2 & 1 & $25-30$ & 3 & $160.2-180.2$ & & \\
\hline Utah & & & & & 4 & 214 & 1 & 20 & 1 & 10 \\
\hline Washington & & & 1 & Unspecified & & & & & & \\
\hline Wyoming & & & & & & & 1 & 0.2 & & \\
\hline Totals & 6 & 20 & 49 & 998.1-1379.9 & 23 & $897-1113$ & 15 & $546.4-914.4$ & 10 & $424.4-552.4$ \\
\hline
\end{tabular}

Nevada has 21 projects in Phase I, but developers did not disclose projected MW values for nine projects.

Phase I: Identifying site, secured rights to resource, initial exploration drilling

Phase II: Exploratory drilling and confirmation being done; PPA not secured

Phase III: Securing PPA and final permits

Phase IV: Production drilling underway, facility under construction

Unconfirmed: Proposed projects that may or may not have secured the rights to the resource, but some exploration has been done on the site

Source: Slack 2008.

Table A2. CSP Developing Projects by Phase

\begin{tabular}{|c|c|c|c|c|c|}
\hline Project Name & Project Owner(s) & $\begin{array}{l}\text { Capacity } \\
\text { (MW) }\end{array}$ & State & $\begin{array}{l}\text { Year in } \\
\text { Service }\end{array}$ & Status \\
\hline Beacon Solar Energy Project & NextEra Energy & 250.00 & $\mathrm{CA}$ & 2012 & Announced \\
\hline Bethel Thermal 1 & Bethel Energy LLC & 49.40 & $\mathrm{CA}$ & 2010 & Advanced Development \\
\hline Bethel Thermal 2 & Bethel Energy LLC & 49.40 & $\mathrm{CA}$ & - & Advanced Development \\
\hline Carrizo Energy Solar Farm & Ausra CA II & 177.00 & $\mathrm{CA}$ & 2010 & Advanced Development \\
\hline Coalinga Solar & Martifer Renewables & 107.00 & $\mathrm{CA}$ & 2011 & Advanced Development \\
\hline Emcore CPV & SunPeak Power & 200.00 & $\mathrm{NM}$ & 2010 & Planning \\
\hline Gaskell SunTower Project & eSolar & 105.00 & $\mathrm{CA}$ & 2011 & Advanced Development \\
\hline Gaskell SunTower Project & eSolar & 140.00 & $\mathrm{CA}$ & 2013 & Advanced Development \\
\hline Harper Lake Energy Park Solar & Harper Lake LLC & 100.00 & $\mathrm{CA}$ & - & Announced \\
\hline Harper Lake Energy Park Solar (Expansion) & Harper Lake LLC & 250.00 & $\mathrm{CA}$ & - & Planning \\
\hline Imperial Valley Solar Project (Solar Two ) & Stirling Energy Systems Inc. & 300.00 & $\mathrm{CA}$ & 2011 & Advanced Development \\
\hline Imperial Valley Solar Project (Solar Two Expansion) & Stirling Energy Systems Inc. & 600.00 & $\mathrm{CA}$ & - & Announced \\
\hline Ivanpah 1 & BrightSource Energy & 100.00 & $\mathrm{CA}$ & 2011 & Advanced Development \\
\hline $\mid \begin{array}{l}\text { Ivanpah } 2 \\
\end{array}$ & BrightSource Energy & 100.00 & $\mathrm{CA}$ & 2011 & Advanced Development \\
\hline $\mid \begin{array}{l}\text { Ivanpah } 3 \\
\end{array}$ & BrightSource Energy & 200.00 & $\mathrm{CA}$ & 2012 & Announced \\
\hline Martin Next Generation Solar Energy Center & Florida Power \& Light Co. & 75.00 & $\mathrm{FL}$ & 2010 & Construction Begun \\
\hline Mojave Solar Park 1 & Solel Inc & 553.00 & $\mathrm{CA}$ & 2011 & Advanced Development \\
\hline Nevada Solar One & Acciona & 64.00 & NV & 2007 & Operational \\
\hline Solana Generating Station & Arizona Solar One & 280.00 & $A Z$ & 2011 & Advanced Development \\
\hline SolarDunes & SkyFuel & 100.00 & $\mathrm{CO}$ & - & Announced \\
\hline Solargenix Saguaro APS Plant & & 1.00 & $\overline{A Z}$ & 2007 & Operational \\
\hline Sopogy Demonstration Plant & Sopogy & 1.00 & $\mathrm{HI}$ & 2009 & Under Construction \\
\hline Southern California Hybrid Solar & Victorville, City of & 50.00 & $\mathrm{CA}$ & 2010 & Announced \\
\hline Victorville 2 Solar & Victorville, City of & 50.00 & $\mathrm{CA}$ & 2011 & Advanced Development \\
\hline Victorville Solar Project (Solar One ) & Stirling Energy Systems Inc. & 500.00 & $\mathrm{CA}$ & 2009 & Advanced Development \\
\hline Victorville Solar Project (Solar One Expansion) & Stirling Energy Systems Inc. & 350.00 & $\mathrm{CA}$ & 2012 & Announced \\
\hline
\end{tabular}

Source: Prometheus/Chad Bourne \& Barke LLP Presentation+ LBNL 


\section{Appendix B. Regional Balances}

The following figures show the relative magnitude of supply and demand projections for all regions defined in the analysis (except Hawaii and Alaska). It should be noted that in some regions, the BAU supply estimates are higher in some years than the high wind case because the allocation of the wind energy capacity among regions is done differently for the two scenarios. The BAU case is based on historic growth in the region, whereas the high wind case uses BTM Consult (2008) market projections for wind energy capacity additions nationally, which are then allocated regionally incorporating the constraints built into the ReEDS model used for the DOE 20\% wind study (DOE 2008).

In the Midwest, both BAU and high wind scenarios show that renewable energy generation would be well in excess of estimated demand in future years (Figure B1). It is interesting to note that the BAU supply scenario, while lower overall on a national basis, shows a higher level of renewable energy generation in the Midwest than under the high wind scenario in some years. The BAU scenario shows significant growth in wind capacity in the Midwest region over the study period because of the large amount of wind capacity added in the region in recent years.

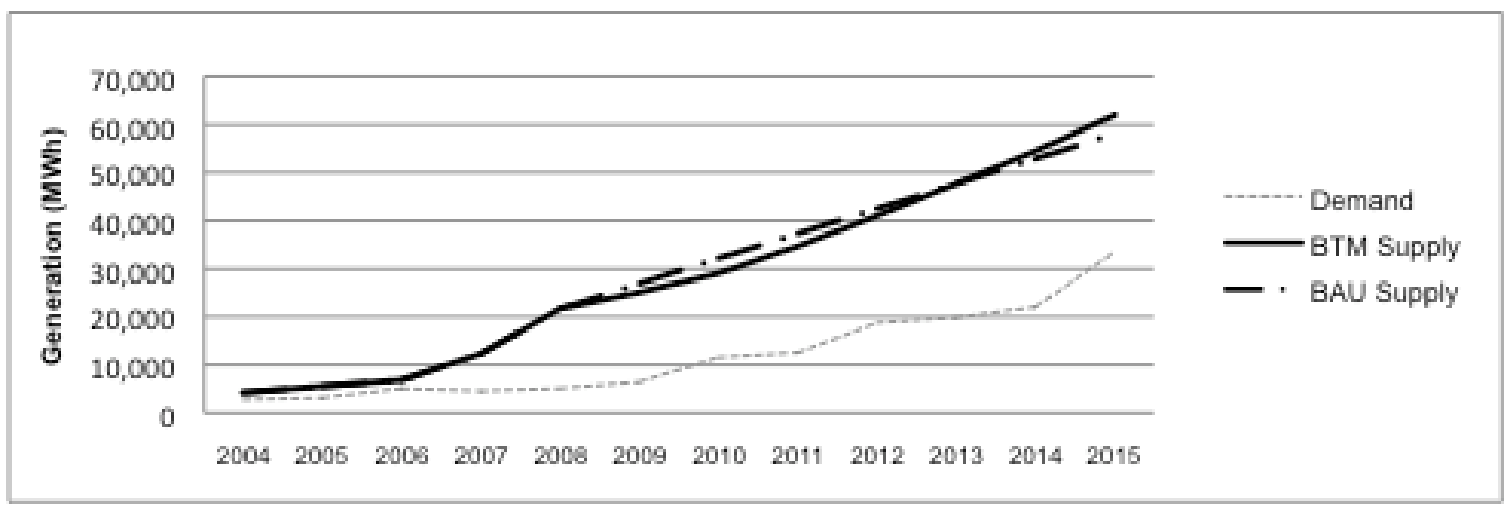

Figure B1. Supply and demand projections for the Midwest, 2004-2015 (MWh)

Figures B2 and B3 show that in New England and New York, demand is projected to outstrip supply over the period of the analysis. Similarly, in the Mid-Atlantic region, demand for renewable energy surpasses both the BAU and high wind scenario projections starting in 2009 (Figure B4). 


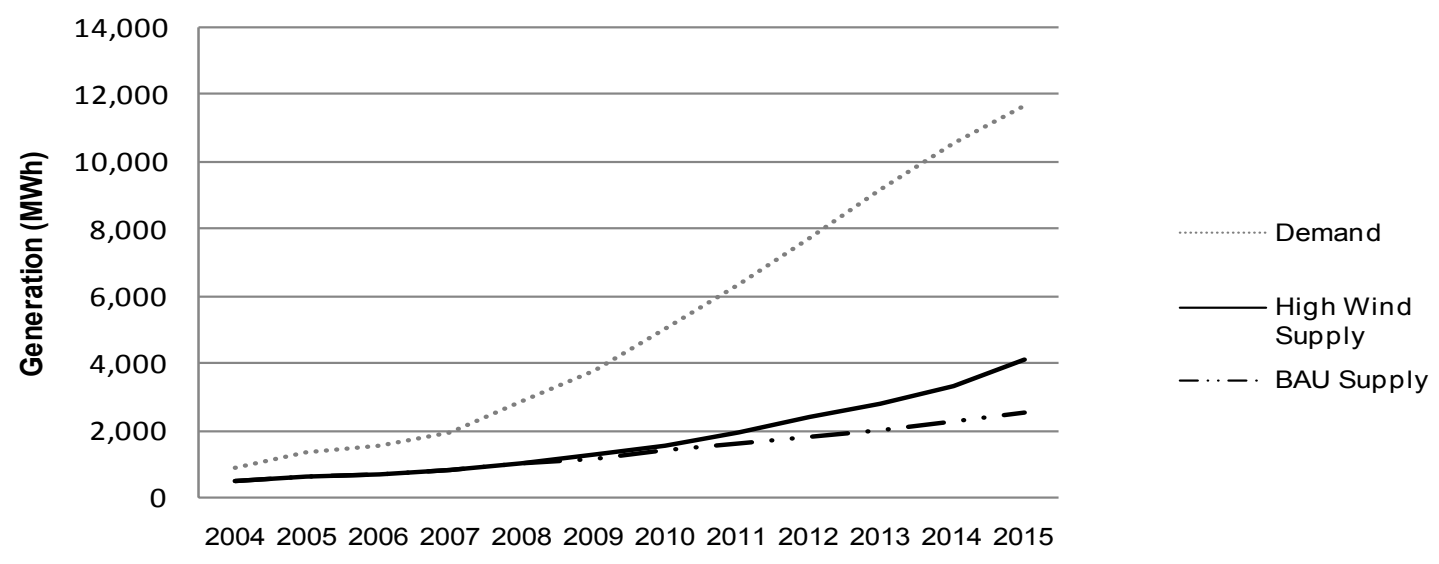

Figure B2. Supply and demand projections for New England, 2004-2015 (MWh)

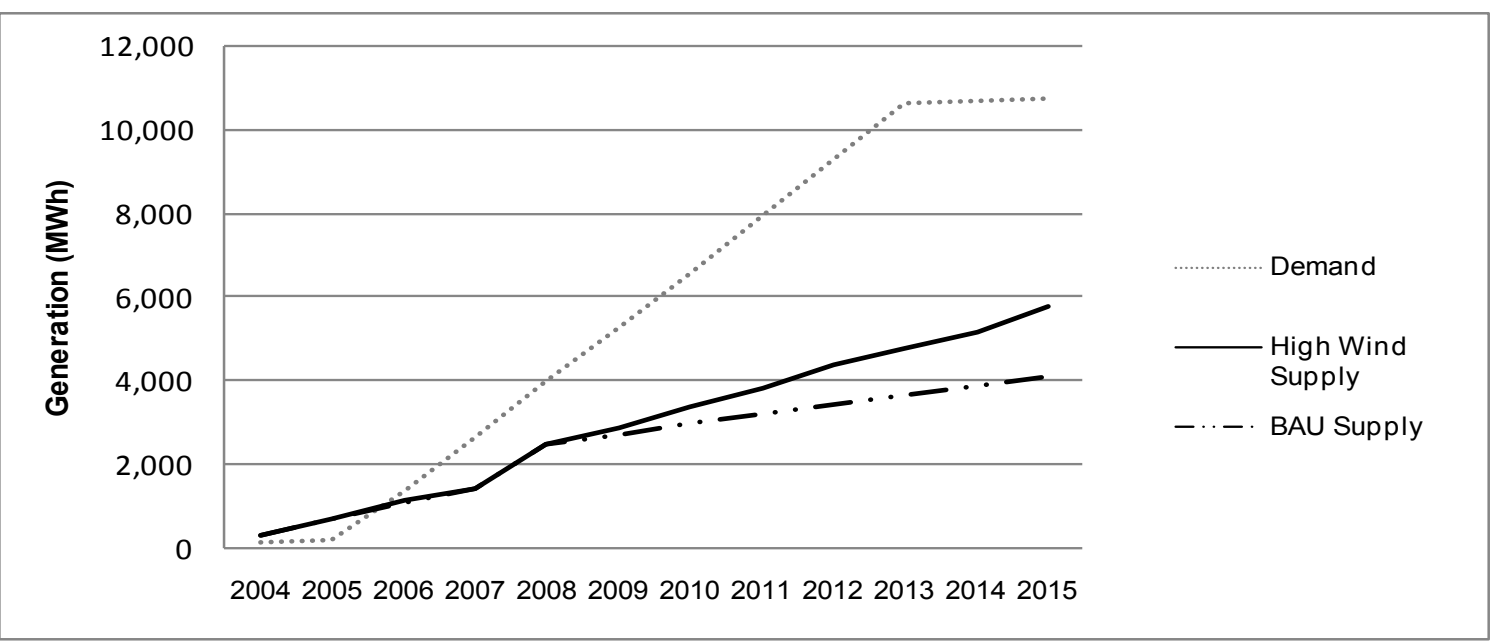

Figure B3. Supply and demand projections in New York, 2004-2015 (MWh)

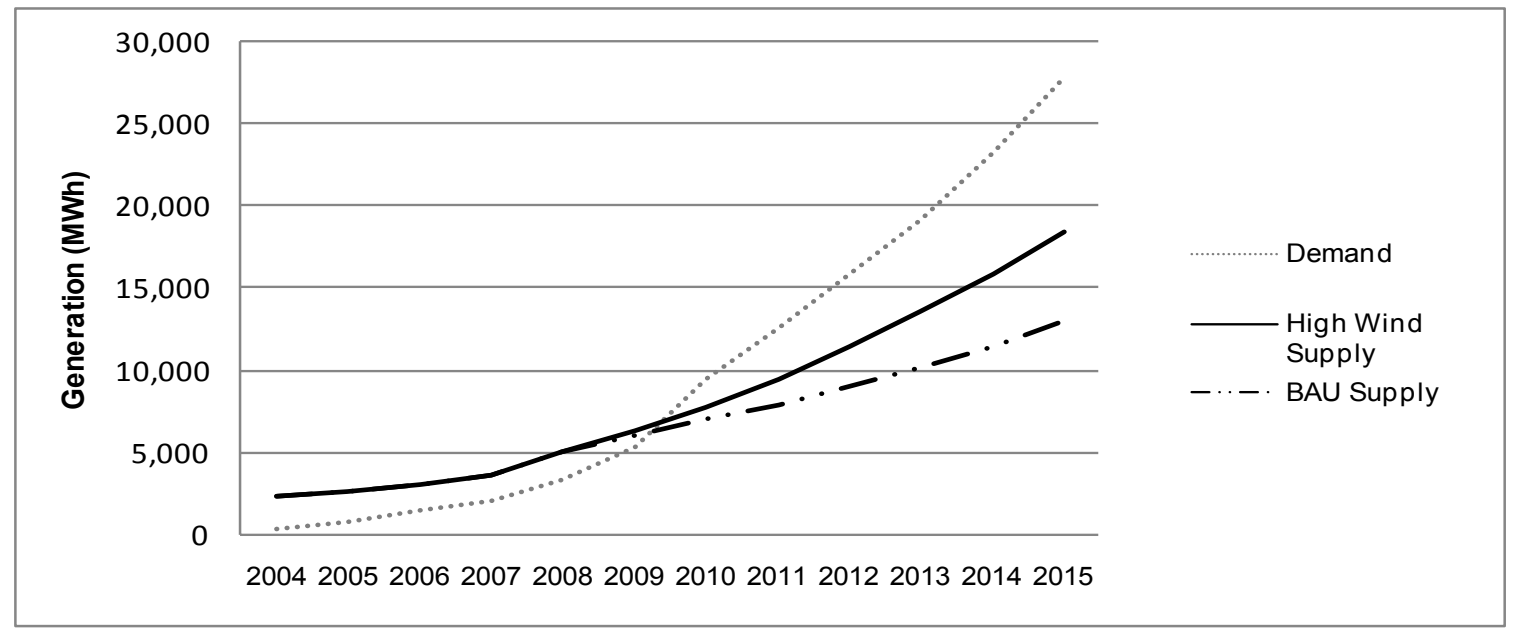

Figure B4. Supply and demand projections in the Mid-Atlantic, 2004-2015 (MWh) 
In the Heartland region, demand is low because Kansas and Oklahoma have no RPS policies (Figure B5). Historical growth of renewables has been slow in the region, so the BAU case shows little growth through 2015. However, due to the quality of the wind resources in the region and estimated supplies in the DOE $20 \%$ wind study, which are used to apportion wind across regions, the high wind case projects that wind development will increase sharply between 2010 and 2015. Neither projection accounts for the recent decision by three Nebraska utilities to join the Southwest Power Pool (SPP), which would expand the RTO's geographic footprint.

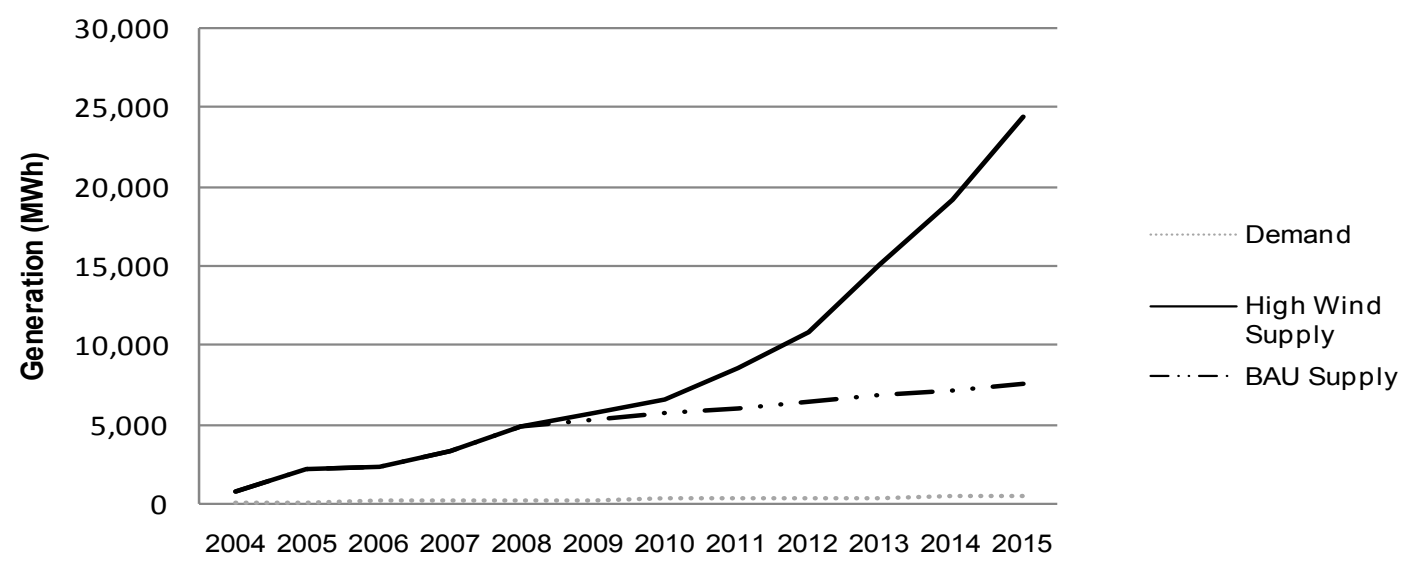

Figure B5. Supply and demand projections in the Heartland, 2004-2015 (MWh)

In the Southeast, demand for renewable energy generation is projected to be low through 2010 and then accelerate as a result of the recently adopted RPS policy in Missouri. Renewable energy supply is projected to exceed demand considerably in the near term, with the gap decreasing in later years (Figure B6).

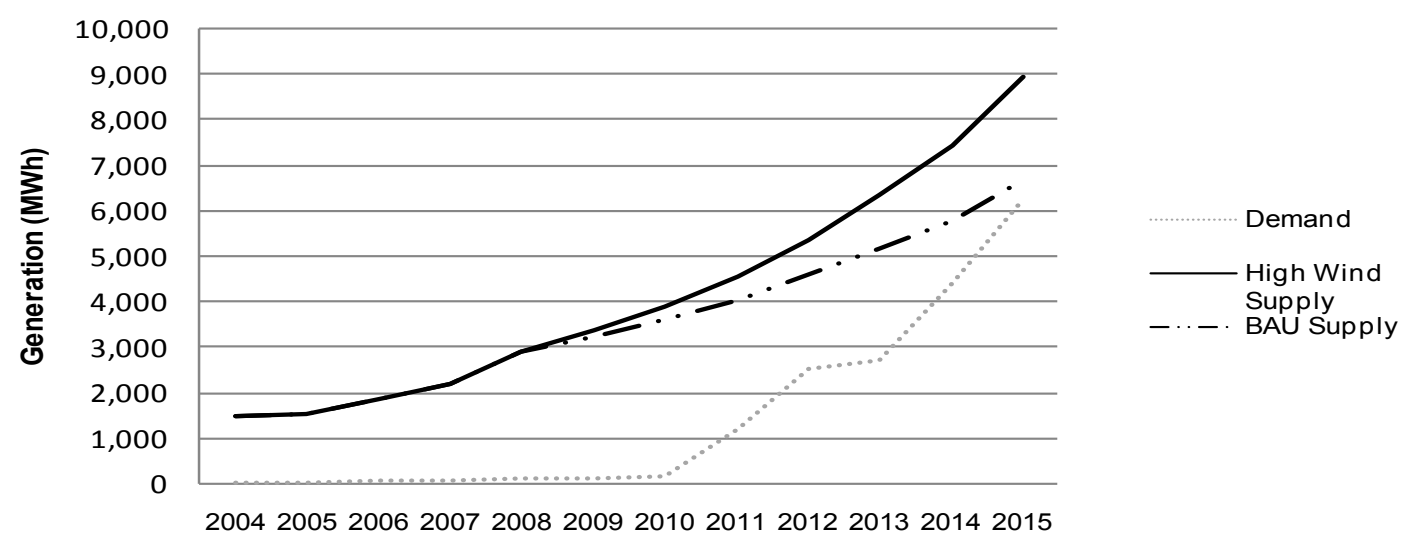

Figure B6. Supply and demand projections in the Southeast, 2004-2015 (MWh)

Figure B7 compares supply and demand for renewables in Florida. Demand for renewable energy generation drops in 2009 because Florida Power and Light terminated 
its green power program. The BAU and high wind supply projections are the same (and appear as a single line in Figure B7) for Florida because no wind is projected to come online in the state under either scenario through 2015.

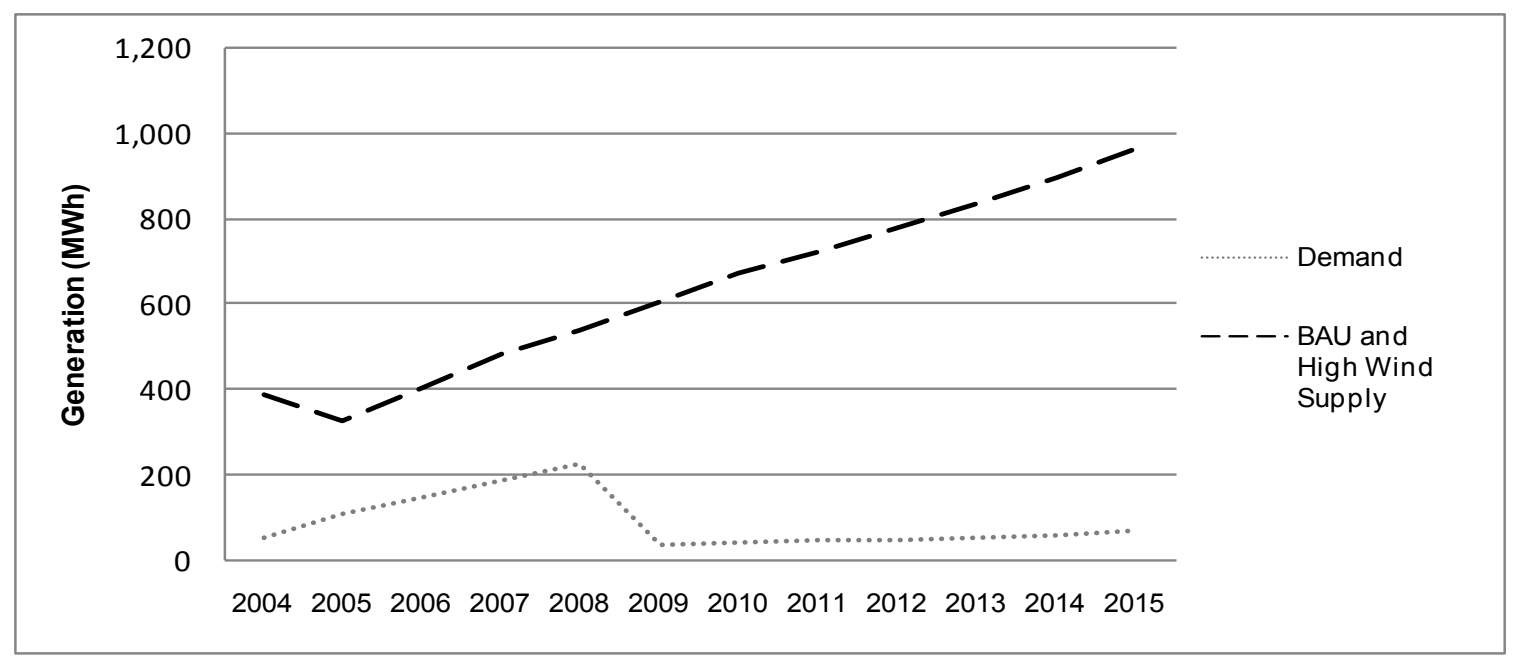

Figure B7. Supply and demand projections in Florida, 2004-2015 (MWh)

Figure B8 shows supply shortages in California under that BAU scenario, starting in 2010. On the other hand, the high wind case shows excess supplies for all years except for 2010. Renewable energy supply projections in the West exceed projected demand through 2015 (Figure B9). It is possible that any shortfalls in California could be met through excess generation from the West to the extent that they can meet California's RPS deliverability requirements. However, interregional transfers were not considered in the analysis - California was treated as a separate region.

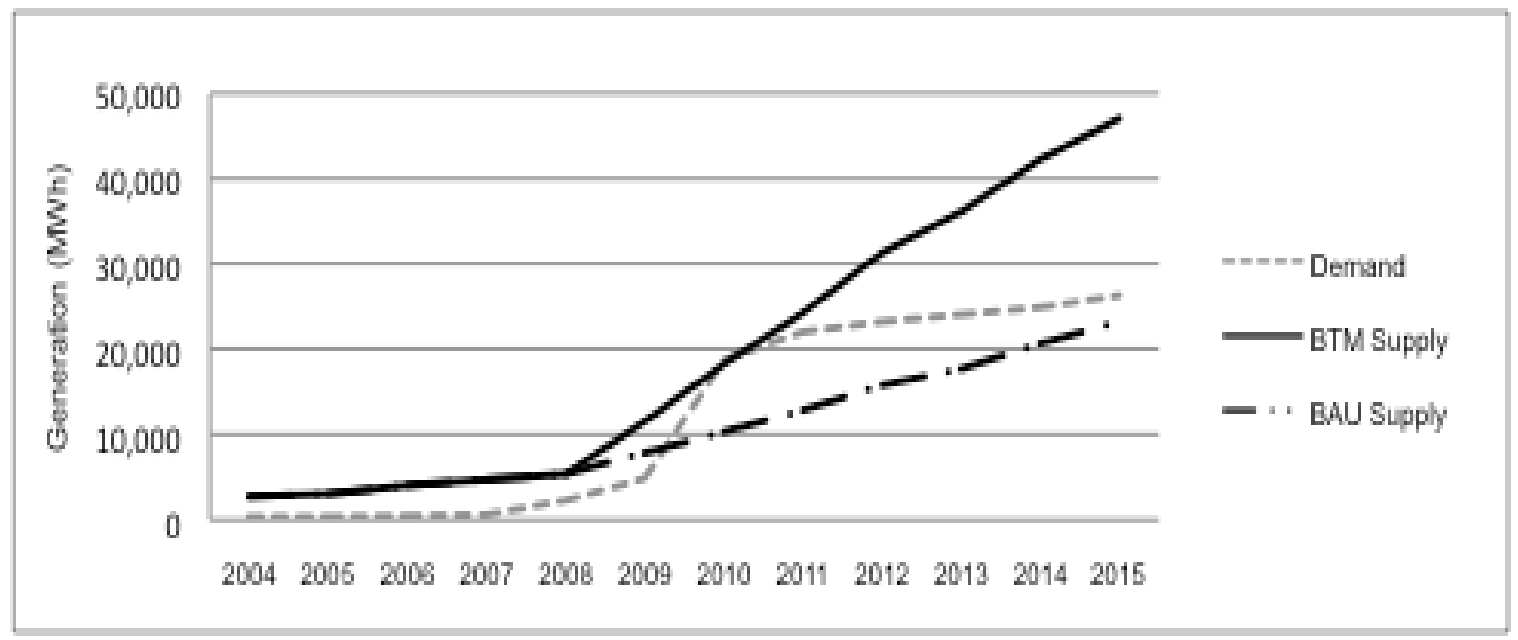

Figure B8. Supply and demand projections in California, 2004-2015 (MWh) 


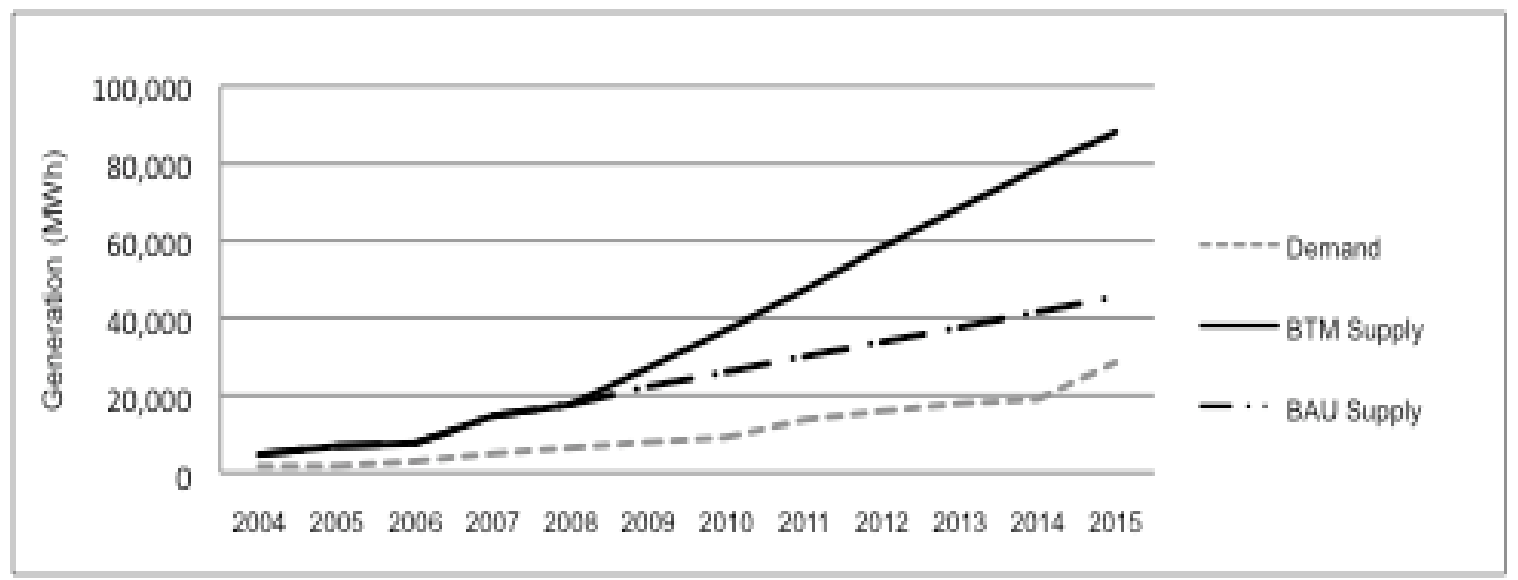

Figure B9. Supply and demand projections in the West, 2004-2015 (MWh)

For Texas, both the BAU and high wind supply projections are similar, and significantly higher than projected demand. Texas has the most installed wind capacity of any state to date; and because of the magnitude of recent wind energy capacity additions, the BAU scenario reflects a high level of growth through 2015. In fact, it is interesting to note that the BAU supply scenario, while lower overall on a national basis, shows a higher level of renewable energy generation in Texas than under the high wind scenario.

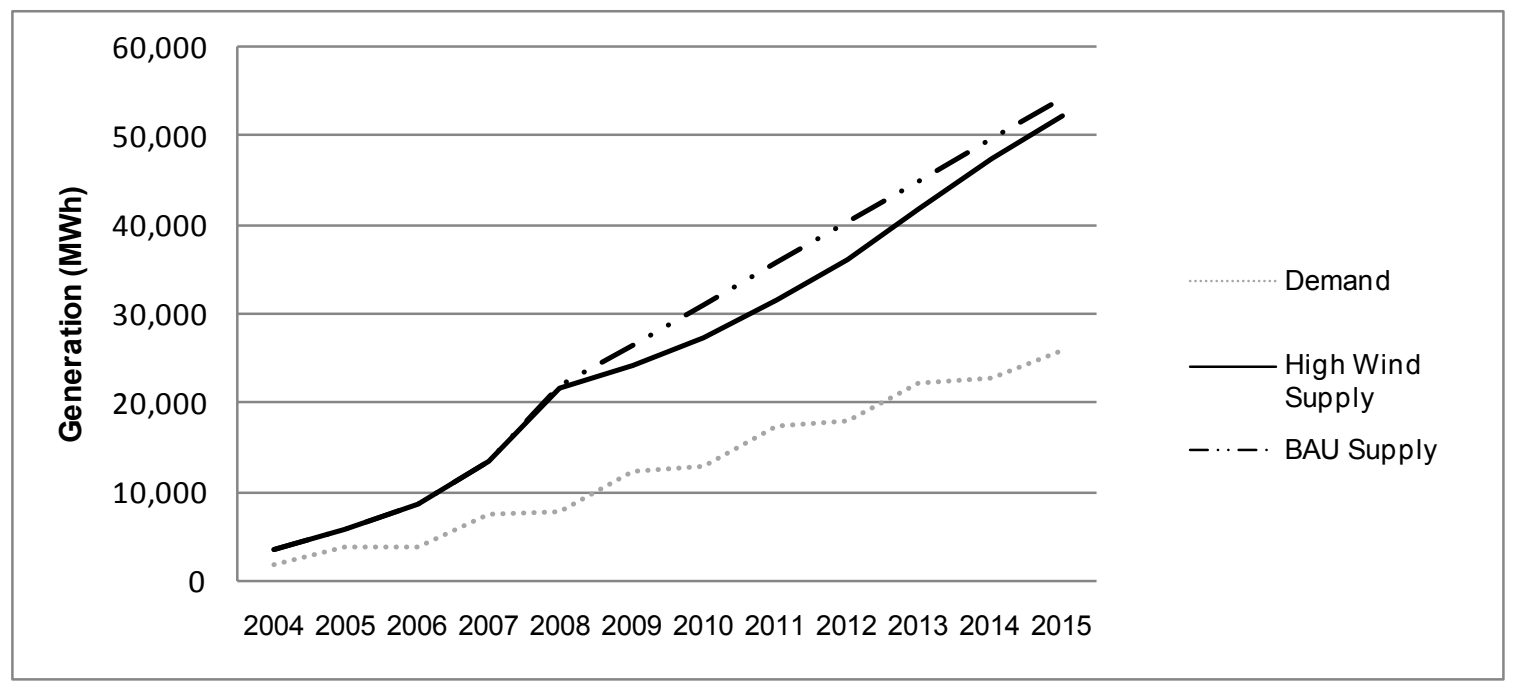

Figure B10. Supply and demand projections in Texas, 2004-2015 (MWh) 


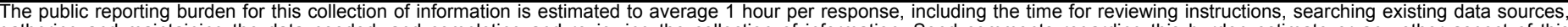

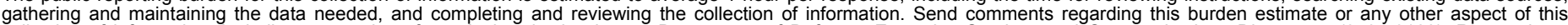

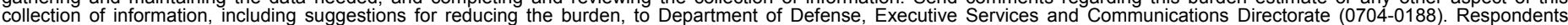

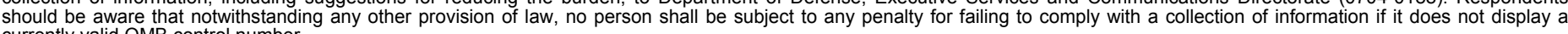

PLEASE DO NOT RETURN YOUR FORM TO THE ABOVE ORGANIZATION.

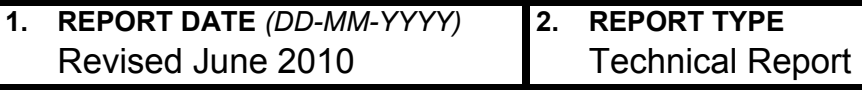

4. TITLE AND SUBTITLE

An Examination of the Regional Supply and Demand Balance for Renewable Electricity in the United States through 2015: Projecting from 2009 through 2015

6. AUTHOR(S)

L. Bird, D. Hurlbut, P. Donohoo, K. Cory, and C. Kreycik
3. DATES COVERED (From - To)

5a. CONTRACT NUMBER

DE-AC36-08-GO28308

5b. GRANT NUMBER

5c. PROGRAM ELEMENT NUMBER

5d. PROJECT NUMBER

NREL/TP-6A2-45041

5e. TASK NUMBER

IGST.8370

5f. WORK UNIT NUMBER
7. PERFORMING ORGANIZATION NAME(S) AND ADDRESS(ES)

National Renewable Energy Laboratory

1617 Cole Blvd.

Golden, CO 80401-3393

9. SPONSORING/MONITORING AGENCY NAME(S) AND ADDRESS(ES)

\section{PERFORMING ORGANIZATION REPORT NUMBER \\ NREL/TP-6A2-45041}

10. SPONSOR/MONITOR'S ACRONYM(S) NREL

11. SPONSORING/MONITORING AGENCY REPORT NUMBER

12. DISTRIBUTION AVAILABILITY STATEMENT

National Technical Information Service

U.S. Department of Commerce

5285 Port Royal Road

Springfield, VA 22161

13. SUPPLEMENTARY NOTES

14. ABSTRACT (Maximum 200 Words)

This report examines the balance between the demand and supply of new renewable electricity in the United States on a regional basis through 2015. It expands on a 2007 NREL study that assessed the supply and demand balance on a national basis. As with the earlier study, this analysis relies on estimates of renewable energy supplies compared to demand for renewable energy generation needed to meet existing state renewable portfolio standard (RPS) policies in 28 states, as well as demand by consumers who voluntarily purchase renewable energy. However, it does not address demand by utilities that may procure cost-effective renewables through an integrated resource planning process or otherwise.

\section{SUBJECT TERMS}

NREL; renewable portfolio standard; RPS; supply and demand; renewable energy certificate; REC; electricity; regional; installed capacity; wind; geothermal; Lori Bird; David Hurlbut; Pearl Donohoo; Karlynn Cory; Claire Kreycik

\begin{tabular}{|l|l|l|l|l|}
\hline 16. SECURITY CLASSIFICATION OF: & $\begin{array}{c}\text { 17. LIMITATION } \\
\text { OF ABSTRACT } \\
\begin{array}{c}\text { a. REPORT } \\
\text { Unclassified }\end{array}\end{array}$ & $\begin{array}{c}\text { b. ABSTRACT } \\
\text { Unclassified }\end{array}$ & $\begin{array}{c}\text { c. THIS PAGE } \\
\text { Unclassified }\end{array}$ & $\begin{array}{c}\text { NUMBER } \\
\text { OF PAGES }\end{array}$ \\
\end{tabular}

